\section{Tank Waste Consolidation Analysis for Transfer of ORNL RH-TRU Tank Sludges to the Melton Valley Storage Tanks}

\section{MASTER}

T. E. Kent

S. M. DePaoli

$$
\begin{gathered}
\text { PEOS } \\
\text { FER } 201997 \\
\text { OSTI }
\end{gathered}
$$


This report has been reproduced directly from the best available copy.

Available to DOE and DOE contractors from the Office of Scientific and Technical Information, P. O. Box 62, Oak Ridge, TN 37831: prices available from (423) 576-8401, FTS 626-8401.

Available to the public from the National Technical Information Service, U.S. Department of Commerce. 5285 Port Royal Road, Springfield. VA 22161.

This report was prepared as an account of work sponsored by an agency of the United States Government. Neither the United States Government nor any agency thereof, nor any of their employees, makes any warranty, express or implied, or assumes any legal liability or responsibility for the accuracy, completeness, or usefulness of any information, apparatus, product, or process disclosed, or represents that its use would not infringe privately owned rights. Reference herein to any specific commercial product, process, or service by trade name. trademark, manufacturer, or otherwise. does not necessarily constitute or imply its endorsement, recommendation, or favoring by the United States Government or any agency thereof. The views and opinions of authors expressed herein do not necessarily state or reflect those of the United States Government of any agency thereof. 


\section{DISCLAIMER}

Portions of this document may be illegible electronic image products. Images are produced from the best available original document. 
Chemical Technology Division

Tank Waste Consolidation Analysis for Transfer of ORNL RH-TRU Tank Sludges to the Melton Valley Storage Tanks

T. E. Kent

S. M. DePaoli

Date Published: January 1997

Prepared by

OAK RIDGE NATIONAL LABORATORY

Oak Ridge, Tennessee 37831-6285

managed by

LOCKHEED MARTIN ENERGY RESEARCH CORP.

for the

U.S. DEPARTMENT OF ENERGY

under contract DE-AC05-96OR22464 
(n) 


\section{CONTENTS}

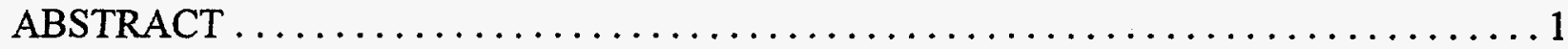

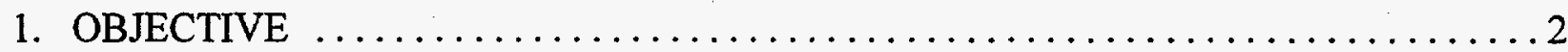

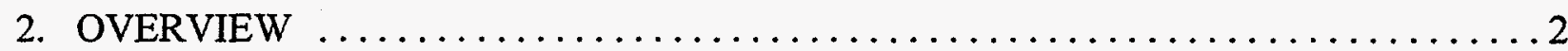

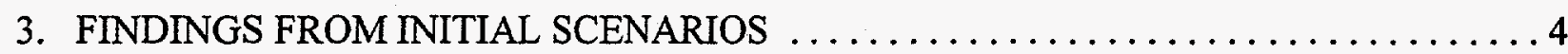

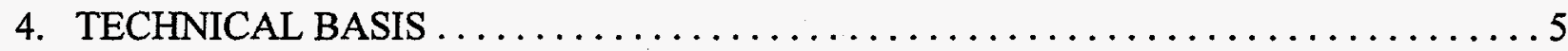

4.1 Tank Farm Sludge Mobilization and Transfer Methods $\ldots \ldots \ldots \ldots \ldots \ldots \ldots 6$

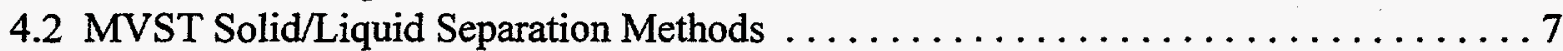

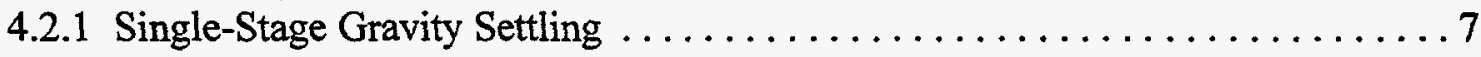

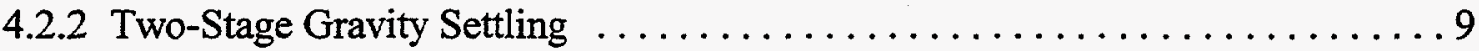

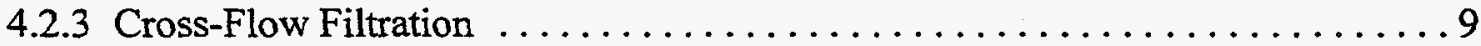

4.2.4 Discussion of SLS Methods .......................... 10

4.3 Evaporation of Sluice Waters and Supernate $\ldots \ldots \ldots \ldots \ldots \ldots \ldots \ldots \ldots \ldots \ldots \ldots$

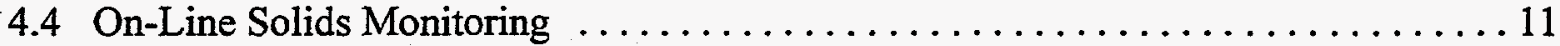

4.5 Solids Content of Transported Sludges $\ldots \ldots \ldots \ldots \ldots \ldots \ldots \ldots \ldots \ldots \ldots \ldots \ldots \ldots$

4.6 Carryover of Suspended Solids to the MVST Capacity Increase Tanks $\ldots \ldots \ldots \ldots 12$

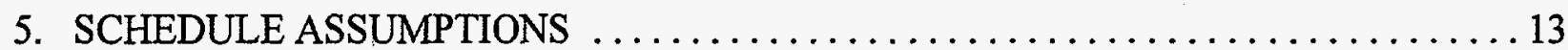

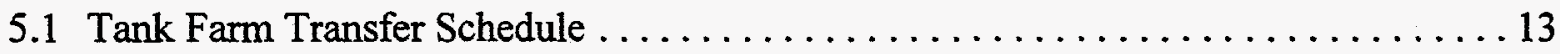

5.2 Schedule for MVST CIT Completion ............................. 14

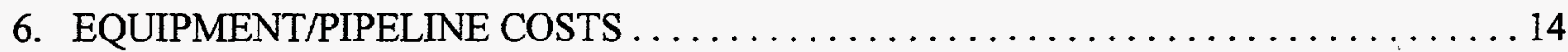

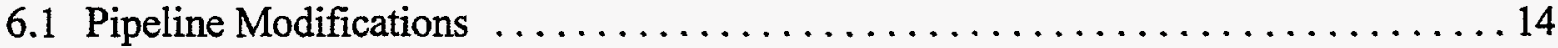

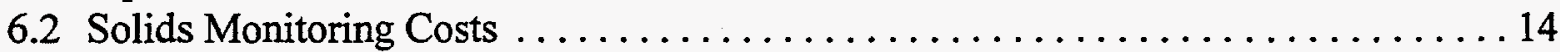

6.3 Cross-Flow Filter System Costs . . . . . . . . . . . . . . . . . . . . 15

6.4 Cost of Fitting CITs for Sludge Mixing and Retrieval $\ldots \ldots \ldots \ldots \ldots \ldots \ldots \ldots \ldots$

7. SUMMARY OF BASELINE WATER BALANCE ANALYSIS $\ldots \ldots \ldots \ldots \ldots \ldots$

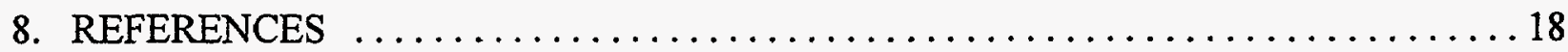

APPENDIX A: WATER BALANCE SPREAD SHEET FOR

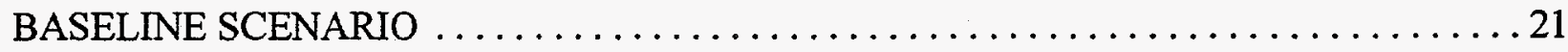




\title{
TANK WASTE CONSOLIDATION ANALYSIS FOR TRANSFER OF ORNL RH-TRU TANK SLUDGES TO THE MELTON VALLEY STORAGE TANKS
}

\author{
T. E. Kent and S. M. DePaoli
}

\begin{abstract}
An evaluation of technical issues and the schedule associated with consolidation of all Oak Ridge National Laboratory (ORNL) Remote Handled Transuranic (RH-TRU) sludges in the Melton Valley Storage Tanks (MVSTs) was performed. The transfer of these sludges must be completed in FY $2000^{\circ}$ to meet the TRU Program milestone for beginning shipment of treated sludges to the Waste Isolation Pilot Plant (WIPP) by 2002. The specific issues addressed in this study included (1) the overall schedule for transferring all RH-TRU sludges to the MVSTs, (2) the ability of the MVST tank system to contain and manage the sludges and liquids generated during the transfers, and (3) the cost and schedule impacts of different solid/liquid separation and solids monitoring methods used during sludge transfer for management of sluice waters. The tank waste consolidation calculations (water balance analyses) involve the use of a simple mathematical model of the tank system in the form of a spread sheet with accurate data on sludge volume, liquid volume, and sludge and liquid compositions. The analyses are performed by first choosing a technical basis for the analysis and then performing spread sheet calculations simulating the transfer of the sludges and liquids from the various tank farms to the MVSTs. Engineering judgement is used to choose the appropriate tank to receive the transfer and the manner in which the transfer sluice water is managed after the transfer. The time required to consolidate all sludges from the three principal ORNL tank farms is driven by the program schedules of the individual tank farms, the amount of additional liquids used to mobilize and transfer the sludges, the availability of additional tank capacity, and the methods used for managing the sludges and sluice waters as they enter the MVSTs. Various sludge consolidation scenarios were developed and evaluated to determine the overall schedule impact and to produce a baseline scenario that results in consolidation of all sludges in FY 2000. It was found that the schedule for transfer of sludges from the ORNL Gunite tanks was the most important driver for the overall sludge consolidation schedule. The use of solids-monitoring devices to allow for greater control of sluice water quantities and the use of a cross-flow filtration system to separate sluice water can reduce schedule requirements, though the impact of these systems on the schedule depends on the ability to accelerate the Gunite tank transfers. A baseline schedule was developed using the latest updated tank farm schedules, solids-monitoring capability, and two-stage gravity settling for managing sluice waters. The results of this analysis indicate that the consolidation of TRU sludges in the MVSTs can be completed by September 2000. There are many key assumptions that significantly influence the baseline plan. Changes in these assumptions must be noted and the water balance calculations rerun as appropriate to evaluate the effect on the schedule.
\end{abstract}




\section{OBJECTIVE}

The objective of this work is to evaluate the schedule and technical issues associated with consolidation of Remote Handled Transuranic (RH-TRU) sludges in the Melton Valley Storage Tanks (MVSTs). This work supports the DOE Transuranic Waste (TRU) Program plans for private sector treatment of all ORNL TRU sludges for disposal at the Waste Isolation Pilot Plant (WIPP). Transfer of these sludges must be completed in FY 2000 to meet the required schedule for beginning shipment of treated sludges to the WIPP by 2002. This study was performed to (1) evaluate the sludge transfer schedule, (2) evaluate the ability of existing tank systems to contain and manage the sludges and liquids generated during the transfers, and (3) evaluate the costs and schedules of different solid/liquid separation and solids-monitoring methods used during sludge transfer for management of sluice waters.

\section{OVERVIEW}

There are three ORNL tank farms containing RH-TRU sludges that require consolidation at the MVSTs: the Gunite and Associated Tanks (GAAT), the Old Hydrofracture Facility tanks (OHF), and the Bethel Valley Evaporator Service Tanks (BVESTs). Figure 1 illustrates the tank farm transfers that will take place. The GAAT consists of eight vertical, cylindrical Gunite tanks containing a total sludge volume of about 44,200 gal and a supernate volume of about 340,000 gal. Two of these tanks have holding capacities of 40,000 gal, and six have capacities of 170,000 gal. The OHF tanks consist of five smaller (13,000- to 25,000-gal capacities), horizontal tanks containing a total of 6,100 gal of sludge and about 37,000 gal of liquid. The BVESTs consist of five horizontal 50,000-gal tanks containing about 38,800 gal of sludge and about 48,300 gal of liquid. The sludges in these three tank farms will be transferred to the MVSTs (eight 50,000-gal horizontal tanks), which currently contain about 101,600 gal of sludge and 196,400 gal of liquid. The sludges from the three tank farms are to be mobilized, retrieved from the tanks, and sluiced with water to the MVSTs by way of an existing double-contained pipeline. Table 1 summarizes estimates for the total volume of sludge and liquids to be transferred to the MVSTs.

Since the MVSTs are already partially filled with sludge and liquid and have a finite volume capacity, the transfer of additional quantities of sludge and liquid must be performed with careful consideration of volume and selection of tank to receive the transfer. Though the physical size of the MVSTs suggests a 400,000-gal capacity, other factors limit the volume of the transfers that can be made to the system. The Operational Safety Requirements (OSR) for the facility limits the total storage volume to $95 \%$ of the capacity, or 380,000 gal. Also, the sludges must be evenly distributed to the tanks. Filling an individual tank completely with sludge would make it very difficult or impossible to mix and mobilize the sludge for later retrieval and treatment activities. Two of the tanks have been designated as decant tanks to be used as a second stage for separating the sludges from the liquids by gravity settling. The amount of sludge transferred to these two tanks must be minimized. 


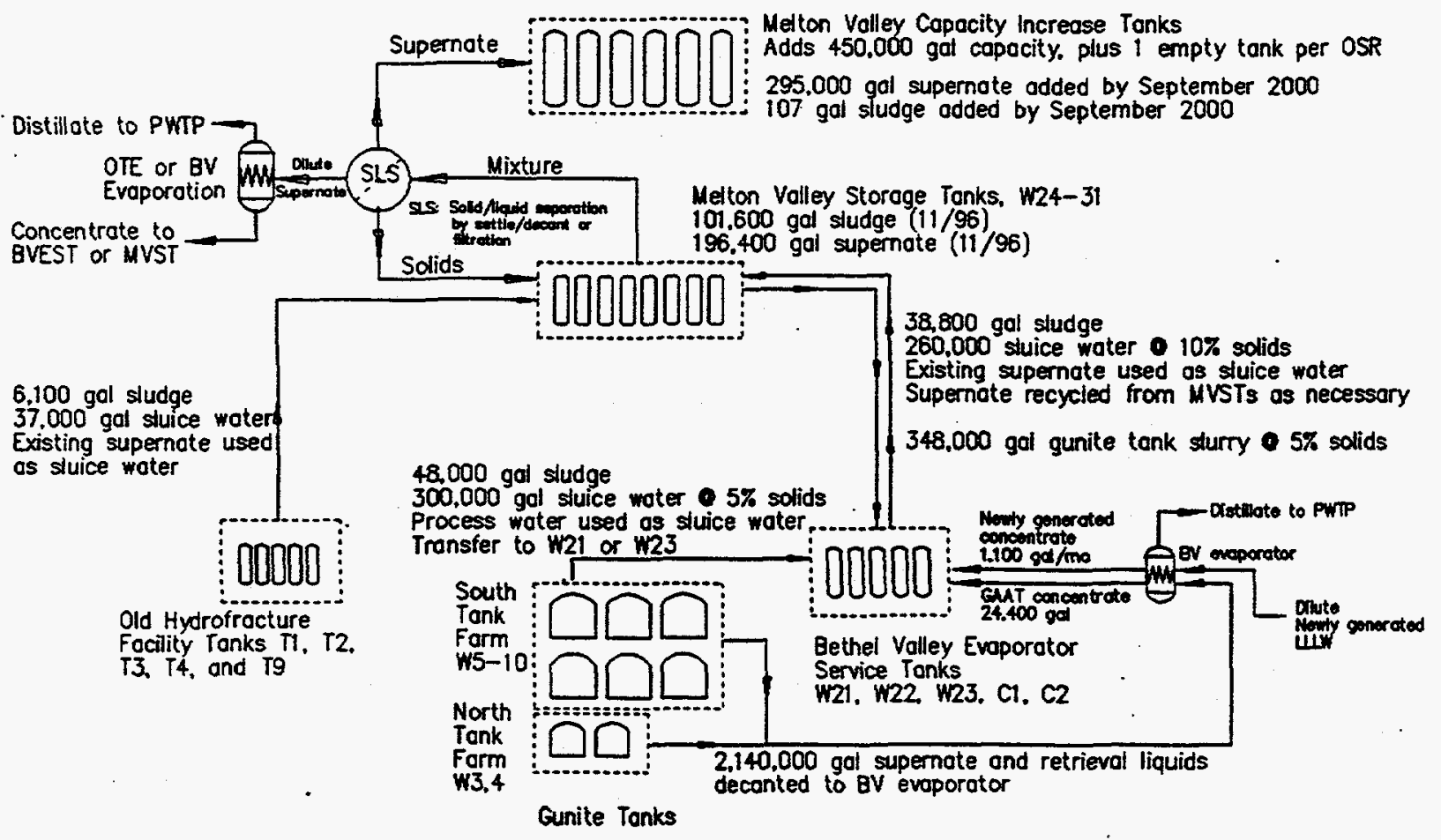

Fig. 1. Flowsheet for consolidation of ORNL RH-TRU sludge in the Melton Valley Storage Tanks. 
Table 1. Summary of tank farm sludge and sluice water volumes

\begin{tabular}{|c|c|c|c|}
\hline Tank farm & $\begin{array}{l}\text { Sludge volume } \\
\text { (gal) }\end{array}$ & $\begin{array}{l}\text { Retrieval and sluice } \\
\text { water volume (gal) }\end{array}$ & $\begin{array}{l}\text { Total liquid and sludge volume to be } \\
\text { managed at the MVSTs (gal) }\end{array}$ \\
\hline $\mathrm{OHF}$ & 6,100 & $37,000^{\alpha}$ & 43,100 \\
\hline BVEST & 38,800 & $\begin{array}{l}260,000^{a} \text { including } \\
\text { recycled supernate }\end{array}$ & 298,800 \\
\hline GAAT & 44,200 & $\begin{array}{l}1,800,000 \text { for } \\
\text { retrieval }^{b} \\
300,000 \text { for transport }\end{array}$ & 344,200 \\
\hline Total & 89,100 & $2,397,000$ & 686,100 \\
\hline
\end{tabular}

${ }^{a}$ Existing supernate used.

${ }^{b}$ Estimated max. volume of process water required for retrieving GAAT sludges and scabbling tank walls.

${ }^{c}$ Estimated volume of process water used to transport GAAT sludges to the MVSTs.

The tank waste consolidation calculations (water balance analyses) involve the use of a simple mathematical model of the tank system in the form of a spread sheet with accurate records of sludge volume, liquid volume, and sludge and liquid compositions, as shown in Appendix A. The analyses are performed by first choosing a technical basis for the analysis and then performing spread sheet calculations simulating the transfer of the sludges and liquids from the various tank farms to the MVSTs. Tank volumes, supernate compositions, and schedules are updated automatically for each transfer activity. Engineering judgement is used to select the appropriate tank to receive the transfer and the manner in which the transfer sluice water is managed after the transfer. The schedule is determined by the number and order of the tank transfers, the solid/liquid separation (SLS) method and time required, the amount of sluice water used in the transfer, the evaporator system used to remove excess water, and other factors. The schedule impact for SLS was determined by running several analyses or "scenarios" in which the SLS method was changed while holding all other factors constant. Similar scenarios were performed to evaluate the schedule impact of solids content for transported slurries and the order of tank farm transfers.

\section{FINDINGS FROM INITIAL SCENARIOS}

The following are the initial findings for the water balance analyses performed during June and July: ${ }^{1,2}$ 
1. The May 1996 baseline schedules for tank transfers would have delayed the completion of the sludge consolidation until as late as February 2002. The transfer schedules for several tank farms required accelerating. A significant improvement to the schedule was realized by transferring BVEST tanks during slack time between GAAT and OHF transfers.

2. Moving the Capacity Increase Tank (CIT) system in-service date from January 1999 to July 1998 results in a nearly corresponding decrease in the time required to consolidate the sludges.

3. Sludge consolidation with two-stage gravity settling took seven months longer than when single-stage settling was used.

4. Cross-flow filtration and solids monitoring systems add significant transfer flexibility, can reduce the consolidation schedule up to 12 months, and reduce or eliminate sludge carryover to the new MVST CIT system.

5. The greatest amount of sludge carryover to the CITs was estimated to be over $5000 \mathrm{gal}$ using single-stage settling for SLS. It was estimated that the use of two-stage settling would reduce carryover to the CITs to less than 1000 gal of sludge.

6. The cost of mixing and retrieving TRU sludges from the CITs was estimated to be $\$ 3.5 \mathrm{M}$ to $\$ 4.5 \mathrm{M}$ based on recent cost estimates for mixing sludges in the MVSTs and BVESTs.

7. Using solids-monitoring devices and increasing the solids content of the transferred sludges from 5 to $10 \mathrm{wt} \%$ reduced the time required for consolidation by ten months.

8. When the MVSTs are transferred to the private sector, the volume of the CIT system will be 60 to $80 \%$ of the OSR limit. This assumes that the BVESTs are not considered part of the storage tank system once they have been cleaned out and returned to service tank status. This also assumes that most of the supernate liquids are transferred from the MVSTs to the CITs.

These initial results prompted several questions regarding scheduling and the technical basis for the study. The technical issues were addressed. To satisfy schedule concerns, meetings were held among the local environmental management program managers to agree on a new integrated schedule for consolidating the sludges. A new technical and schedule basis for the study was prepared and used for an updated water balance analysis.

\section{TECHNICAL BASIS}

The following describes the technical basis and assumptions used in analyzing the tank sludge consolidation scenarios. 


\subsection{TANK FARM SLUDGE MOBILIZATION AND TRANSFER METHODS}

The methods used to mobilize and transfer sludges from the tank farms to the MVSTs govern the composition and subsequent treatment of the liquids after the transfers. Dilute liquids, such as those from OHF and GAAT transfers, are sent to the BVEST evaporator system for evaporation and disposal of the liquid condensate by way of the Process Waste Treatment Plant (PWTP). BVEST transfers are made using existing high-salt, concentrated supernate liquids. These liquids must be managed by SLS, followed by either recycle to the BVESTs or transfer to the CIT system.

The OHF tanks will use a combination of single-point sluicing and in-tank mechanical mixing to accomplish the mobilization and transfer of sludges. Single-point sluicing involves the use of a single sluice jet mounted near the top of the tank. The sluice jet uses a moderate-pressure (100-psi) spray directed at the settled sludge to mobilize the sludge. Once mixed, the sludge slurry is pumped from the tank using progressive-cavity (Moyno) pumps. The slurry is transferred to a smaller consolidation tank equipped with mechanical (FLYGT) mixers designed to keep the sludge suspended in the liquid. Transfer pumps at the consolidation tank are used to move the sludge to the MVSTs. Since the OHF supernates are fairly dilute, the liquids will be transferred to the BVEST evaporator for processing after separating from the sludges at the MVSTs.

The GAAT system will use the Modified Light Duty Utility Arm (MLDUA) with a high-pressure confined sluicing end-effector (CSEE) and jet-pump transfer system to mobilize and retrieve the sludges from the tanks. The retrieved sludges will be transferred through in-line grinders and consolidated in GAAT tank W-9 prior to transfer to the BVEST W-21 or W-23. The pulse-jet system in W-21 or W-23 will be used to transfer the GAAT sludges to the MVSTs. The schedule may dictate that one or more GAAT tanks be transferred directly to the BVESTs without interim consolidation in W-9. Due to the inherent risks of the high-pressure system used for the CSEE, process water will be used instead of the existing contaminated supernate liquids to mobilize and retrieve the sludges. The bulk of the excess sluice water will be removed from the slurry at W-9 by settling and decanting. The decanted liquid will be transferred directly to the BVEST evaporator from W-9. The sluice water used to transfer the GAAT slurry to the MVSTs from the W-21 or 23 will be decanted and returned to the BVESTs for further sluicing of sludges or for processing in the evaporator. The initial water balance scenarios assumed that the contents of the GAAT tanks would be transferred directly to the MVSTs one at a time, with several months allowed in between transfers for moving the MLDUA equipment to the next tank. This complicated the schedule by having to interrupt transfers from other tank farms to allow for the periodic GAAT transfers. The new plan for consolidating in W-9 can be performed outside the MVST transfer schedule and allows other tank farms to complete sludge transfers to the MVSTs without delays. After consolidation, the sludge in W-9 will be transferred to the BVESTS and on to the MVSTs in a continuous transfer campaign. 
The BVEST sludges will be mobilized using a pulse-jet mixing system designed and fabricated by AEA Technology of the United Kingdom. This system operates by moving fluid in and out of the existing tank nozzles. BVEST tanks W-21,22, and 23 have three opposing pairs of 3-in.diameter nozzles located along the length of the tank. C-1 and C-2 tanks do not have nozzles but have manhole extensions installed to provide access for nozzles. The centerline of the nozzles in the W-tanks is nominally 8 in. off the bottom of the tank. Each nozzle will be connected to one of the pulse-jet system charge vessels. Fluidic pumps are used to create a vacuum in the charge vessel, pull fluid from the tank into the vessel, and discharge the fluid under pressure into the tank. The pulsing of the fluid back into the tank mixes the sludge with the tank supernate to produce a uniform mixture. The frequency and pressure used for the pulses are adjusted to control the degree of mixing. Existing Moyno pumps will be used to transfer the mixed slurry to the MVSTs. Since existing supernate is used, concentrating by evaporation is not necessary and the liquids must be separated from the sludge and transferred either to the CITs or returned to the BVESTs for further sludge mixing and transfer.

\subsection{MVST SLS METHODS}

The methods used to transfer the sludges and to manage the supernate liquids will have a significant impact on the cost and schedule for these operations. Since the MVSTs have limited capacity for holding the sluice waters, SLS is necessary to separate the sluice water from the sludge and remove it from the MVSTs. The sluice water will be managed in one of three ways: (1) transfer to evaporator systems for concentrating, (2) transfer to the BVESTs to recycle as sluice water, or (3) transfer to the CITs for storage. If the Out-of-Tank evaporator (OTE) system is to be used to concentrate the sluice water, the feed to the evaporator must be free of TRU sludges. Traces of TRU sludges in the OTE feed will lead to significant contamination concerns because the OTE system is located in Building 7877 and is designed for hands-on maintenance activities. The liquids sent to the CITs must also be free of TRU sludges because the new tanks are not designed for mixing and mobilizing the sludge and because ORNL made a commitment to the Tennessee Department of the Environment and Conservation not to store TRU sludges in the new tanks.

Three different methods for separating and managing the liquids and sludges were evaluated: (1) single-stage gravity settling, (2) two-stage gravity settling, and (3) filtration. Flow sheets for these methods are shown in Fig. 2.

\subsubsection{Single-Stage Gravity Settling}

Single-stage gravity settling involves an operation presently performed by Waste Management Operations (WMO) prior to transferring supernate between tanks. If sludge has been recently added to a particular tank, the sludges are allowed to settle for a two-month period. The dip leg for the suction line to the pump is well below the level of the sludge in the tank; therefore, the transfer to the targeted tank is preceded by transferring a "slug" of tank sludge/liquid slurry to another MVST designated as the "catch" tank. Following the slug transfer, it is assumed that the sludges are compacted enough to create a cavity around the dip leg and allow transfer of 


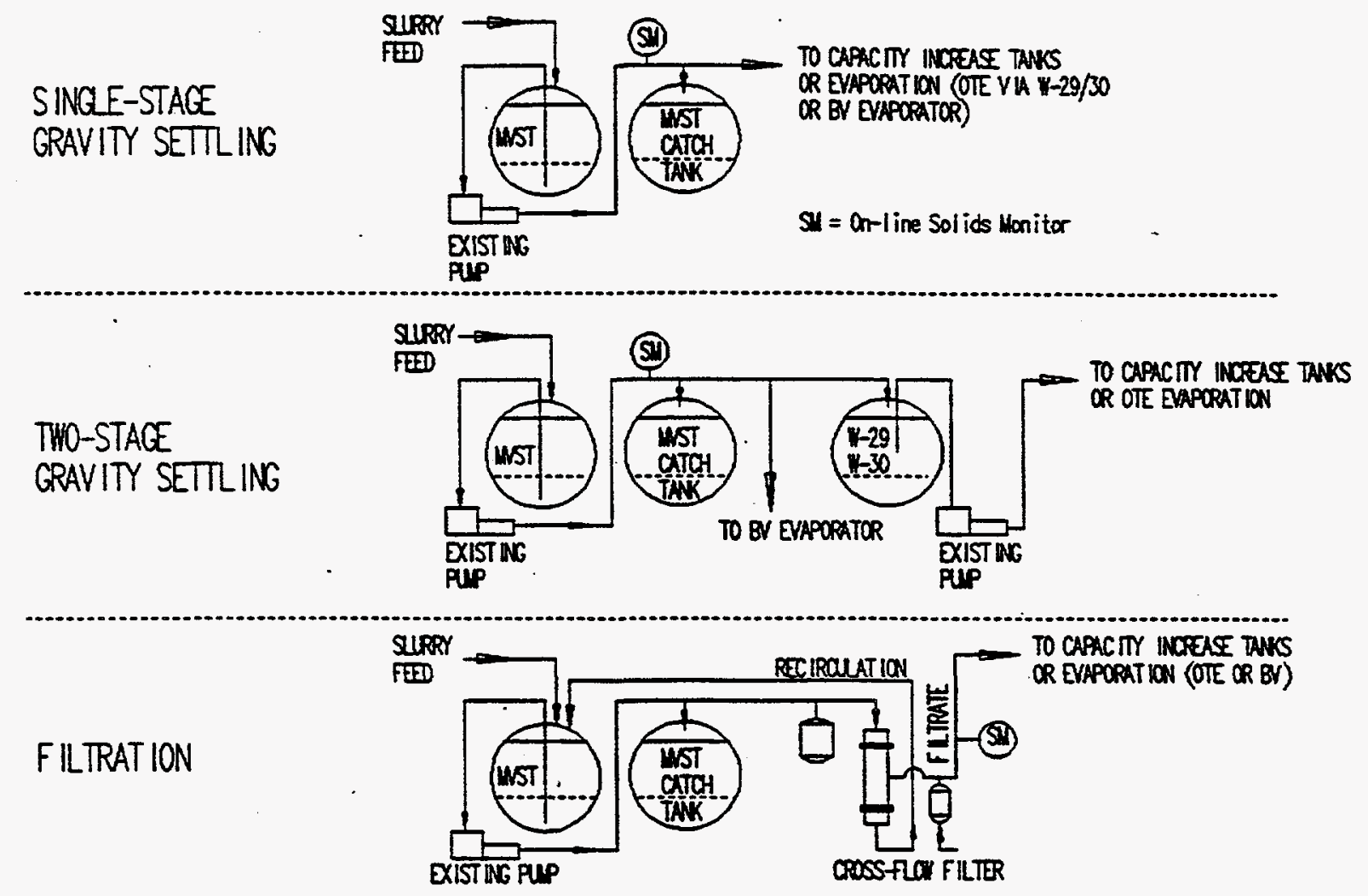

Fig. 2. Solid/liquid separation flow sheets. 
supernate with a relatively low suspended solids content to the targeted tank. It was assumed that some carryover of sludge would occur during these transfers. For a sludge that had not recently been disturbed, it was assumed that $1 \%$ of the sludge would be carried over to the CITs or other receiving tanks during the transfer (i.e., for a tank containing 10,000 gal of sludge, 100 gal of sludge would be carried over). For sludge that had settled for two months in the MVSTs after a sluicing operation, it was assumed it would be much more fluid in nature and that $5 \%$ of the new sludge would be carried over to the receiving tank. Since very little is known about the physical characteristics of these sludges, the assumptions made are based on best engineering judgement and the past qualitative testing by Fowler, ${ }^{3}$ as described in Sect. 4.6. Though it is strongly suspected that carryover will occur, the actual amounts could be less than or greater than the amounts estimated.

\subsubsection{Two-Stage Gravity Settling}

Two-stage gravity settling involves an operation presently performed by WMO prior to performing a Liquid Waste Solidification Project (LWSP) or OTE. In this operation, the singlestage settling described above is followed by transfer of the supernate to either of tanks W29 or W30 to allow additional settling prior to transfer to the CITs. W29 and W30 are equipped with decant legs which reach no lower than the 50\% (25,000-gal) level in the tanks. Rough estimates indicate that each of these tanks contain about 11,000 gal of sludge. It was assumed that one month would be allowed for the second stage of settling. It has been shown that supernates decanted from W29/30 for LWSP do not contain significant amounts of sludge; therefore, it was assumed that preexisting sludges in the MVSTs would not carry over into the CITs when twostage settling is performed. Recently transferred sludges that have been pulverized to particle sizes less than $100 \mu \mathrm{m}$, will be more difficult to settle, and it was assumed that the second stage of settling would reduce carryover to $0.5 \%$ of the volume of the new sludge.

If sludge settling actually occurs faster than the one to two months assumed for gravity settling, there is a potential opportunity to shorten the transfer schedule by reducing the settling time. Sludge settling tests with actual samples of MVST Tank W-25 sludge and GAAT sludge were performed to determine the settling rate of the solids. The tests indicated that the bulk of the sludge would settle in less than one week; however, the settled sludge volume was larger and less dense than the original sludge. The data indicated that it would take much longer for the sludge to compress to its original volume. Though the flow characteristics of the sludge layer were not determined in the hot testing, it was assumed that time must be allowed for the sludge to compress to a level close to its original volume and thus minimize the amount of sludge that would be carried over to W-29 and W-30 decant tanks during the two-stage settling. On this basis, it was decided not to reduce the recommended settling time for the sludges.

\subsubsection{Cross-Flow Filtration}

Filtration involves the installation and use of a cross-flow filtration system for treatment of all supernate liquids during the transfers. Cross-flow filtration involves the use of porous metal 
tubular filters through which the supernate is pumped under pressure. The filter element consists of a tube bundle within a cylindrical shell, similar to a shell and tube heat exchanger. The liquid/solid mixture is pumped through the tube side of the element at a fairly high velocity and recirculated to the feed tank under moderate pressure (20 to $40 \mathrm{psi}$ ). The solids content of the filtrate would be extremely low, and it was assumed that no measurable quantity of sludge would be transferred with the filtrate. The filtrate rate was assumed to be about $5 \mathrm{gal} / \mathrm{min}$, which is what would be expected using a $50-\mathrm{ft}^{2}$ surface area filter element (about $10 \mathrm{ft}$ long and 12 in. in diam). Additional filter elements could be added to increase filtrate flow rate, though this would increase pump requirements for recirculating the slurry through the elements. The filter element is backwashed by applying a pressurized pulse of fluid in the opposite direction of the filtrate flow from the shell side of the filter element. This is performed using air pressure from a cylinder installed on the filtrate piping. The filter can also be chemically cleaned with dilute nitric acid if it becomes plugged. It was assumed that the MVSTs would serve as feed tanks for the filter and no settling time would be necessary prior to processing.

\subsubsection{Discussion of SLS Methods}

Though the single-stage gravity settling is the simplest method and can be done in a relatively short time, it is the most likely to result in significant carryover of TRU sludge. The filtration method is the only method out of the three that is capable of removing all TRU sludges from the liquids and meeting the needs of OTE and the commitment made to Tennessee Department of Environment and Conservation. However, filtration will require time and money for designing, fabricating, and installing. Two-stage settling is simple and much more effective than singlestage settling. However, there are several real and potential problems associated with two-stage settling: (1) available tank space is occupied by settling activities, (2) the settling duration has a significant impact on the overall consolidation schedule, (3) TRU solids may be carried over to the CITs or OTE system, and (4) the sludge level in tanks W-29 and W-30 may increase to the point that the second stage of decanting is not possible.

Earlier water balance scenarios illustrated the schedule advantage of single-stage settling and filtration SLS methods. These scenarios also indicated that the transfers would not be complete until the 2002 time frame if two-stage settling were used. However, the early analyses were based on outdated tank farm transfer schedules. When these schedules were updated and accelerated, the two-stage settling method resulted in completion of the sludge consolidation in FY 2000, within the time required for private sector construction activities. Since two-stage settling will likely result in the transfer of small amounts of sludge to the CITs, the commitment to TDEC must be renegotiated. Plans must also be prepared for the eventual accumulation of sludge in the CITs and the potential costs for sludge removal. Additionally, the first stage of settling must allow sludges to settle long enough to minimize carryover during transfer to decant tanks W-29 and W-30. The baseline water balance scenario assumes the use of two-stage gravity settling for SLS during MVST sludge consolidation. 


\subsection{EVAPORATION OF SLUICE WATERS AND SUPERNATE}

The OTE system will be used to create additional storage space in the MVSTs and CITs by. concentrating the supernate to nitrate levels up to $8 M$. Due to the relatively low processing rate for OTE, the large-volume, dilute sluice waters from the GAAT sludge transfers will be returned to the BVEST evaporator for processing. The BVEST evaporator system can produce distillate at a rate of $5 \mathrm{gpm}$ compared with the OTE system rate of $1 \mathrm{gpm}$. The BVEST evaporator, however, cannot be used to concentrate the supernate to concentrations to greater than $4 \mathrm{M}$ nitrate due to pipeline transfer limitations.

\subsection{ON-LINE SOLIDS MONITORING}

For mobilization, mixing, and transport of sludges to the MVSTs, it will be important that the concentration of solids in the slurry be monitored and controlled. The solids content of the slurry must be high enough to avoid transport of large quantities of excess water to the MVSTs but low enough to avoid conditions that could lead to plugging of the slurry transfer pipeline. Sampling of the slurries and analysis can be performed to monitor solids content; however, sampling and analysis is slow, labor intensive, and does not provide real-time data. This study assumes that on-line solids-monitoring devices are used during the slurry transfers where appropriate. The installation of on-line devices requires short-term radiation exposure and a significant investment; however, the advantages include (1) the minimization of radiation exposure from sampling and analysis of hot samples, (2) obtaining real-time indication of slurry conditions, and (3) the ability to respond quickly to process changes. Section 6.2 includes a comparison of costs and operating issues for sampling and on-line solids monitoring.

\subsection{SOLIDS CONTENT OF TRANSPORTED SLUDGES}

The amount of sluice water used to transport the tank sludges though the pipeline to the MVSTs has a direct impact on the MVST capacity and the time required to manage the sluice waters by evaporation or by transfer to the CITs (for storage) or BVEST (for additional sluicing). The amount of sluice water or solids content assumed during transport depends on the retrieval and transfer method chosen for each particular tank farm.

In the previous water balance analyses, it was assumed that the solids content for the slurry transfer would be a maximum of $5 \mathrm{wt} \%$ for all transfers. This was a conservatively low solids content compared with what has been accomplished in the past during the 1984 Gunite tank transfers. Transfers of $15 \mathrm{wt} \%$ and sometimes higher solids content slurries were achieved using bentonite suspending agents. The $5 \mathrm{wt} \%$ assumption was based on the likelihood that (1) the mobilization of GAAT sludge heals and the scarifying of the gunite tank walls would require enough sluice water to dilute the slurries to $5 \mathrm{wt} \%$ or less and (2) sluicing for the BVEST sludge would also require a large excess of sluice water. However, new information indicated that the solids content would depend on the retrieval method chosen for each particular tank farm. 
GAAT sludge transfer plans have changed several times, which has made it necessary to modify the assumption for solids content of the GAAT slurries. One of the former plans for the GAAT sludge retrieval included the use of a conditioning system to grind and dewater the slurries. Under these conditions, it was assumed that the GAAT sludge could be transferred to the MVSTs at an overall concentration of $10 \mathrm{wt} \%$. However, a later decision was made to consolidate GAAT sludges in tank W-9 for settling and decanting of sluice water in lieu of installing the conditioning system. In-line grinding of the sludge will be performed during transfer to W-9. After decanting the retrieval waters to the BVEST evaporator, W-9 sludges will be retrieved and transferred by the same method as the other GAAT tanks to BVEST tank W-21 or W-23. The pulse-jet mixing system installed in W-21 and W-23 in FY 1997 will subsequently be used to remobilize the GAAT sludges and transfer them to the MVSTs. Since the GAAT conditioning system will not be available, the latest consolidation scenario assumed an average $5 \mathrm{wt} \%$ slurry for transport of GAAT sludge to the BVESTs and from the BVESTs to the MVSTs.

For the OHF transfers, characterization information suggests that mixing all the supernates and sludges in these tanks will result in a slurry with a solids content of about $8 \mathrm{wt} \%$. The current OHF plans indicate that the volume of existing supernate should be adequate for retrieval and transport of the sludges; therefore, the anticipated volume of water to be managed at the MVSTs was assumed to be the volume of the existing OHF supernate.

In the case of the BVEST sludges, the use of the pulse-jet system is expected to make possible the retrieval and transfer of $10 \%$ solids slurries to the MVSTs. Since mixing and transfer of BVEST sludges will be performed simultaneously, the use of on-line solids monitors is critical for control of the process.

\subsection{CARRYOVER OF SUSPENDED SOLIDS TO THE MVST CAPACITY INCREASE TANKS}

Since there is a lack of physical data on the sludges, only best engineering judgement could be used to assume the amount of carryover that would occur as a consequence of decanting after gravity settling of the sludges. Initial scenarios assumed carryover of $1 \%$ of preexisting sludge and $5 \%$ of newly transferred sludge in the MVSTs to the CITs.

Tests were performed by Vic Fowler in 1994 that provide some qualitative data using a 250-gal Plexiglas model of an MVST and a simulated sludge. ${ }^{3}$ The test program was originally performed to help Waste Management Operations determine the optimum operating procedure for minimizing sludge carryover to tanks W-29 and W-30 after single-stage settling when preparing for a LWSP campaign. The tests were focussed on comparing transfer procedures, not determining exact quantities of sludge that would be transferred. The main findings of the study were as follows:

1. The procedure being used by Waste Management Operations involved recirculating the tank using the existing progressive cavity (Moyno) pumps prior to beginning the 
supernate transfer. This procedure reduces sludge carryover by clearing out sludge near the suction leg and creating a depression in the sludge layer.

2. Carryover could be reduced further by limiting the quantity of supernate transferred to $90 \%$ or less of the total supernate volume. This avoids the fluidization of the sludge caused by the higher velocity travel of the supernate across the surface of the sludge as the supernate level approaches the sludge level.

3. It was qualitatively estimated that sludge carryover could be limited to less than $125 \mathrm{gal}$ for a 25,000 -gal supernate transfer from a tank containing 18,850 gal of sludge; that is, $0.66 \%$ of the sludge in the tank is carried over.

Since the Fowler study result was qualitative in nature, used simulated sludge, and was reasonable close to the assumed $1 \%$ for the preexisting sludge, the assumptions made for the water balance analyses were not changed.

\section{SCHEDULE ASSUMPTIONS}

\subsection{TANK FARM TRANSFER SCHEDULE}

The schedule for tank farm transfers has been modified many times since the initiation of the water balance studies. Earlier studies showed that the consolidation in the MVSTs required too much time based on the initial tank farm transfer plans. Waste Management and Environmental Restoration Programs recently developed an integrated schedule for the transfers, which has accelerated the transfer plans for the tank farms to meet the required TRU program schedule for sludge consolidation.

In initial water balance schedules, the BVESTs were not to be transferred until after the completion of the GAAT tanks in FY 2000. Recent development of the BVEST Incentive Task Order (ITO) project involves a technology demonstration of the pulse-jet system in BVEST tank W-21 to occur in September 1997. It is now assumed that the sludge transfer from W-21 will be performed as part of the ITO. This transfer will be followed by transfer of all of the OHF tank sludges, which will require about six months, beginning in January 1998. The BVEST transfers will be resumed after OHF with W-23, W-22, C-1, and C-2.

The retrieval of sludge and scarifying of the walls of the Gunite tanks is expected to require about six months per tank. The consolidation in W-9 will begin with the North Tank Farm tanks W-3 and W-4 in August 1997 and continue with South Tank Farm (STF) tanks over the period of about two years. To reduce the schedule requirement by about three months, the baseline plan calls for the early transfer of one of the STF tanks to the MVSTs via the BVEST mixing and transfer system beginning in October 1999. The W-9 transfer to the MVSTs via the BVESTs is expected to begin by February 2000. 


\subsection{SCHEDULE FOR MVST CIT COMPLETION}

It was assumed in earlier scenarios that the MVST CITs would not be in service until January 1999. This assumption was considered unacceptable because it was a key factor in delaying the overall consolidation schedule beyond FY 2000. In follow-on scenarios, it was assumed that the CIT schedule could be accelerated to a completion date of July 1998. This is a key schedule assumption because the CITs create critical storage capacity for sluice waters from the MVST sludge consolidation.

\section{EQUIPMENT/PIPELINE COSTS}

The following section provides information on the potential cost impacts of pipeline modifications and equipment additions necessary for management of sluice waters transferred to the MVSTs along with the sludges.

\subsection{PIPELINE MODIFICATIONS}

Pipeline modifications are necessary to increase the processing rate of the OTE system and for allowing the use of Building 7877 for OTE, the Cesium Removal Demonstration (CsRD) System, and/or LWSP from the CITs. The estimated cost of the CIT pipeline to Building 7877 is $\$ 550 \mathrm{~K}$ to $\$ 650 \mathrm{~K}$ based on previous experience with the MVST Decant System piping necessary to connect W-29 and W-30 to Building 7877. The cost of the MVST Decant System in FY 1987 was $\$ 505 \mathrm{~K}$. This included purchase and installation of the W-29 and W-30 dip legs, about $200 \mathrm{ft}$ of stainless steel double-contained shielded piping, and the associated pump module. It is assumed that the pipeline installation was $75 \%$ of the cost or $\$ 380 \mathrm{~K}$. Escalating $5 \%$ per year for 10 years results in an estimated cost of about $\$ 580 \mathrm{~K}$. The feasibility and costs for installing the decant system as part of the MVST CIT construction project is currently being evaluated.

\subsection{SOLIDS MONITORING COSTS}

Solids monitoring instrumentation would allow on-line monitoring of suspended solids content during transfers. The scenarios described assume that on-line solids monitoring capability is provided. If on-line monitoring is not provided, manual sampling of decanted liquids or filtrate must be performed. A qualitative comparison of costs and issues associated with on-line monitoring and manual sampling was performed. The results indicate that the costs are comparable. Radiation exposure is received by workers in both cases: (1) during installation of on-line solids monitors and (2) during handling and analysis of sludge samples. A summary of the estimated costs for the two solids monitoring alternatives is given in Table 2 . 
Table 2. Comparison Summary of Solids Monitoring Methods

\begin{tabular}{|c|c|c|}
\hline Criteria & Sampling and analysis & On-line solids monitoring \\
\hline Equipment costs & $\begin{array}{l}\text { \$10K [lead pigs, personal } \\
\text { protective equipment (PPE)] }\end{array}$ & $\$ 20$ to $\$ 30 \mathrm{~K}$ \\
\hline Installation costs & $\$ 5 \mathrm{~K}$ & $\$ 50 \mathrm{~K}^{a}$ \\
\hline Routine labor costs & $\$ 30 \mathrm{~K}$ (sampling) & \$5K (calibration) \\
\hline Analytical costs & $\begin{array}{l}\$ 40 \mathrm{~K}(100 \text { samples @ } 4 \mathrm{~h} \text { per } \\
\text { sample, } \$ 100 / \mathrm{h})\end{array}$ & NA \\
\hline Radiation exposure & $\begin{array}{l}\text { Routine low exposures from } \\
\text { sample handling and analysis. }\end{array}$ & $\begin{array}{l}\text { Single moderate exposure during } \\
\text { installation of monitor. Infrequent } \\
\text { low exposures during calibration. }\end{array}$ \\
\hline Schedule impact & $\begin{array}{l}\text { Several-month impact from } \\
\text { sampling time and waiting for } \\
\text { analytical results before transfer of } \\
\text { slurries. }\end{array}$ & Minimal \\
\hline Waste disposal costs & $\begin{array}{l}\text { \$10K (handling and } \\
\text { documentation) }\end{array}$ & Included in installation costs \\
\hline $\begin{array}{l}\text { Future decontamination and } \\
\text { decommissioning }\end{array}$ & $\mathrm{NA}$ & $\begin{array}{l}\$ 20 \text { to } \$ 30 \mathrm{~K} \text { (removal and disposal } \\
\text { of monitor) }\end{array}$ \\
\hline Total estimated costs & $\$ 95 \mathrm{~K}$ & $\$ 95$ to $\$ 115 \mathrm{~K}$ \\
\hline
\end{tabular}

${ }^{a}$ Cost assumptions:

Work plans, permits - $160 \mathrm{~h}$ Engineering, drawings $-80 \mathrm{~h}$ Installation - $200 \mathrm{~h}$

Electrical, calibration $-80 \mathrm{~h}$
Waste disposal - $40 \mathrm{~h}$

Materials - \$2K (PPE)

$30 \%$ contingency $-168 \mathrm{~h}$

$(728 \mathrm{~h} \times \$ 67 / \mathrm{h})+\$ 2=\$ 50 \mathrm{~K}$

\subsection{CROSS-FLOW FILTER SYSTEM COSTS}

Previous water balance studies indicate that the addition of cross-flow filtration provides operational flexibility and can compress the transfer schedule by as much as 12 months. The amount of sludge carried over to the CITs is assumed to be insignificant, and there would be no future costs associated with retrieval and treatment of CIT sludge. The cost of design, installation, operations, and D\&D for the filtration system is estimated at $\$ 1.85 \mathrm{M}$ and is broken down as follows: 


\section{Cost estimate for cross-flow filter system at the MVSTs}

Task

Design

Equipment and fabrication

Documentation

Training

Assessments

Installation

Operations

D\&D

Total cost

$\frac{\text { Cost }}{\$} 130,000$
$\$ 700,000$

$\$ 100,000$

$\$ \quad 40,000$

$\$ 60,000$

$\$ 220,000$

$\$ 200,000$

$\$ 400,000$

$\$ 1,850,000$
Design by private sector

Procure major components and fabricate skidmounted system by private sector

Environmental compliance documentation and safety study

Install in cubical adjacent to MVSTs

Startup and operations

Future cost

Filtration provides the capability to reduce the time required for managing sluice waters and compress the overall consolidation schedule. Gravity settling for 25,000 gal of slurried sludge at the MVSTs will require a minimum of one month. If the cross-flow filter is designed for a filtrate flow rate of $5 \mathrm{gal} / \mathrm{min}$, filtration of 25,000 gal would require only 3.5 days. This could be particularly important if schedule delays are experienced due to equipment problems or other causes.

\subsection{POTENTIAL COST OF FITTING CITS FOR SLUDGE MIXING AND RETRUEVAL}

To determine the cost consequences of adding sludges to the CITs, the cost of mixing, retrieving, and treating the sludges was estimated. It was assumed that the treatment of the sludges would be included in the private sector contract for treatment of the MVST sludges. The cost of the mixing system was estimated based on previous cost estimates for mobilizing sludges in the MVSTs and BVESTs. In September 1995, a proposal entitled "MVST Sludge Mobilization Demonstration Proposal" (X-OE-773) was prepared by the Lockheed Martin Energy Systems Central Engineering Services and the Chemical Technology Division. The estimated cost of the preferred option, involving installation of a combination single-point sluicer and submerged-jet sluicer system, was \$4.2M. In October 1996, an Incentive Task Order proposal entitled "BVEST Sludge Mixing Demonstration and Transfer" was prepared which proposes the use of a pulse-jet mixing system designed and fabricated by AEA Technology. The estimated cost of the demonstration was $\$ 3.5 \mathrm{M}$. Since the CIT tanks are larger than both the MVSTs and the BVESTs, the costs will be slightly higher and estimated to be about $\$ 4.5 \mathrm{M}$.

\section{SUMMARY OF BASELINE WATER BALANCE ANALYSIS}

Table 3 summarizes the basis for the baseline water balance scenario. This scenario will serve as a baseline for subsequent analyses. Factors that significantly affect cost and schedule of the plan 
Table 3. Assumptions and conditions for the baseline water balance analysis

\begin{tabular}{|c|c|}
\hline Parameter & Description \\
\hline Solids monitoring & $\begin{array}{l}\text { On-line solids-monitoring devices are used where appropriate for transfer of sludges to the } \\
\text { MVSTs. }\end{array}$ \\
\hline Solid/liquid separation & $\begin{array}{l}\text { - Two-stage settling will be used at the MVSTs to separate sluice water and transfer to either the } \\
\text { CIT system or to the BVESTs for evaporation or for mobilizing additional BVEST sludges. } \\
\text { - A two-month settling time is allowed for the first stage and one-month settling for the second } \\
\text { stage. } \\
\text { - If liquids are to be transferred to the BVESTs as either recycled sluice water or evaporator feed, } \\
\text { single-stage settling is provided with a one-month duration for settling. }\end{array}$ \\
\hline Sludge carryover & $\begin{array}{l}-0.5 \% \text { of newly transferred sludge will carry over into the CITs. } \\
\text { - None of the preexisting sludge will carry over during two- stage gravity settling. }\end{array}$ \\
\hline Solids content of slurry & $\begin{array}{l}\text { OHF }-8 w t \% \text { solids } \\
\text { GAAT }-5 w t \% \text { solids } \\
\text { BVEST }-10 w t \% \text { solids }\end{array}$ \\
\hline Out-of-tank evaporator & $\begin{array}{l}\text { - OTE is used to concentrate existing supernates at the MVSTs to a maximum of } 8 \mathrm{M} \text { nitrate. } \\
\text { - Treatment capacity is } 1 \mathrm{gal} / \mathrm{min} \text {. Each OTE campaign lasts about one month. } \\
\text { - A total of } 43,000 \mathrm{gal} \text { of distillate is removed from the MVSTs in four OTE campaigns. }\end{array}$ \\
\hline BVEST evaporation & $\begin{array}{l}\text { - Dilute sluice waters are transferred to the BVEST evaporator for processing. } \\
\text { - Peak processing capacity is } 5 \mathrm{gal} / \mathrm{min} \text {. } \\
\text { - It is acceptable to transfer small amounts of sludge to the BVEST feed tank W-22. }\end{array}$ \\
\hline $\begin{array}{l}\text { Newly generated liquid } \\
\text { low level waste (LLLW) }\end{array}$ & $\begin{array}{l}\text { - Newly generated LLLW is produced at a rate of } 13,000 \text { gal/year. } \\
\text { - Newly generated LLLW is stored in BVESTs. }\end{array}$ \\
\hline Pipeline flushes & $1000 \mathrm{gal}$ of process water is used to flush the MVST pipeline after each transfer. \\
\hline BVEST transfers & $\begin{array}{l}\text { - W-21 is transferred in } 9 / 97 \text {. } \\
\text { - W-22, W-23, C-1, and C-2 are transferred after OHF. } \\
\text { - Existing supernate is used for sluicing sludges. Supernate is recycled from the MVSTs for } \\
\text { additional transfers. } \\
\text { - W-22 will use dilute evaporator feed supernate for sludge transfer. }\end{array}$ \\
\hline OHF transfers & $\begin{array}{l}\text { - Transfers begin in January } 1998 \text { and are complete in six months. } \\
\text { - Existing supernate is used in transfers. } \\
\text { - Little or no supernate recycle is necessary. }\end{array}$ \\
\hline GAAT transfers & $\begin{array}{l}\text { - Most of the GAAT sludge is consolidated in W-9 prior to transfer. } \\
\text { - Early transfer of one STF tank begins September } 1999 \text {. } \\
\text { - W-9 transfer begins February } 2000 \text {. } \\
\text { - Existing GAAT supernate is transferred directly to the BVEST evaporator for processing. } \\
\text { - Process water is used to retrieve and transfer the sludges. } \\
\text { - The majority of the water used to retrieve the sludges is decanted from W-9 and transferred } \\
\text { directly to the BVEST evaporator. }\end{array}$ \\
\hline CIT system & $\begin{array}{l}\text { - CITs are in service by July } 1998 \text {. } \\
\text { - It is acceptable to transfer small amounts of TRU sludge to the CITs. }\end{array}$ \\
\hline
\end{tabular}


include (1) the schedule for the tank farm transfer operations, (2) the volume of sluice water, (3) the in-service date for the CITs, and (4) the time required for settle/decant activities. If an assumption is revised, the water balance must be reanalyzed to determine the impact on the overall schedule.

A time line schedule for this transfer scenario is given in Fig. 3. A summary of initial and final tank volumes and supernate nitrate and cesium content for the baseline scenario is provided in Table 4. The spread sheet showing detailed results of tank transfer activities with volume and composition data is provided in Attachment A.

The results of this analysis indicate that the consolidation of TRU sludges in the MVSTs will be complete by September 2000. There are several key events associated with this plan. The BVEST sludge mobilization demonstration must be successful using the pulse-jet system; otherwise, an alternative system will have to be designed and installed, resulting in significant delays. The MLDUA retrieval system, a GAAT technology demonstration, must be successfully operated and the plan for consolidation in W-9 must be approved. As experience is gained in working with the MLDUA and associated equipment, the actual time required for the GAAT operation may change. Similarly, the OHF retrieval and transfer equipment must operate as planned to meet this schedule. Key events such as these and changes in the above assumptions can significantly impact the integrated transfer schedule. Changes in the assumptions must be noted and the water balance calculations rerun as appropriate to evaluate schedule impacts.

\section{REFERENCES}

1. T. E. Kent and S. M. DePaoli, personal communication to F. J. Homan, June 19, 1996.

2. T. E. Kent and S. M. DePaoli, personal communication to F. J. Homan, July 11, 1996.

3. V. L. Fowler, personal communication to C. B. Scott, Mar. 24, 1994. 


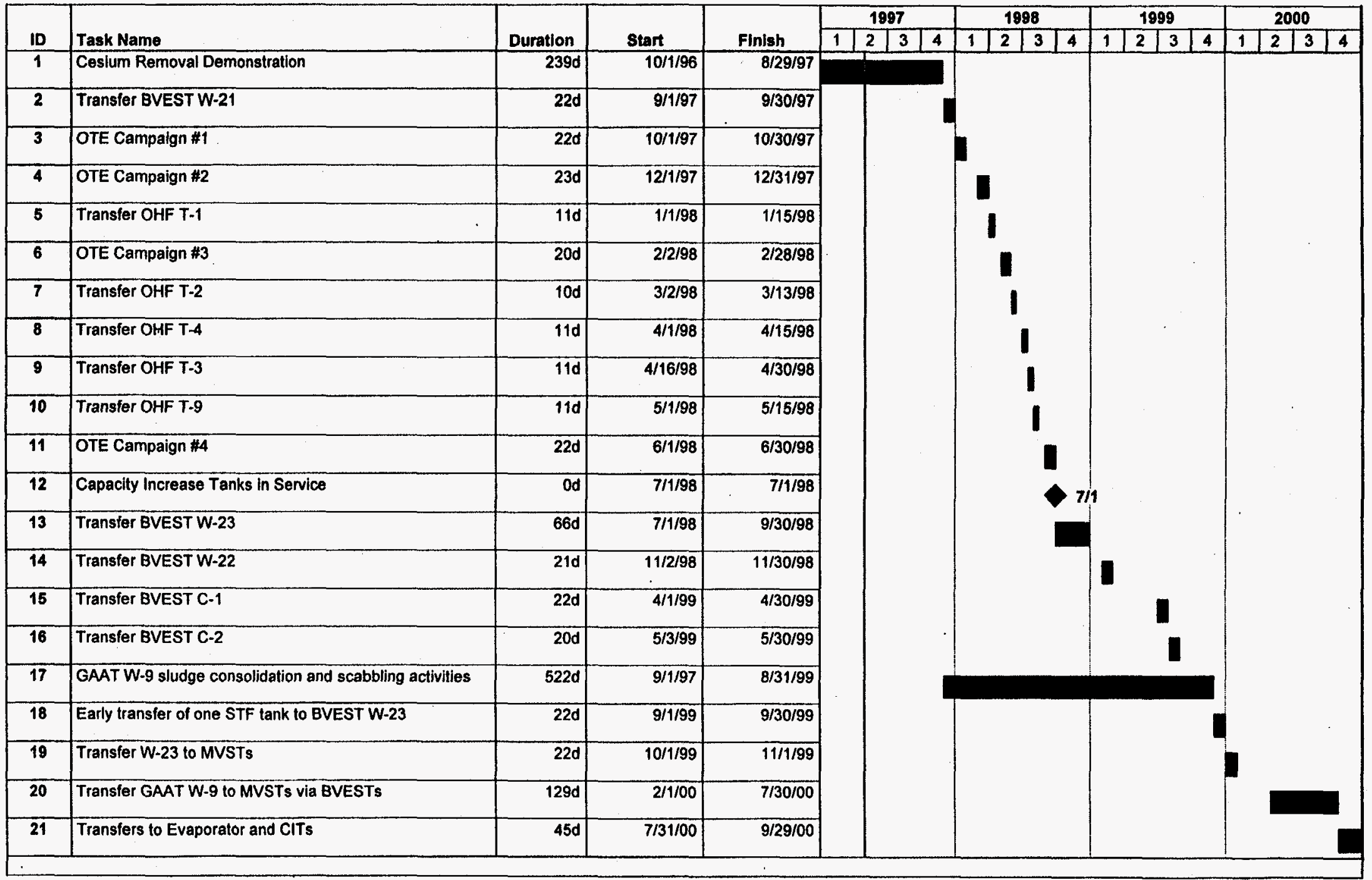

Fig. 3. Schedule for consolidation of ORNL RH-TRU sludges in the Melton Valley Storage Tanks. 
Table 4. Summary of MVST and CIT conditions before and after sludge consolidation

\begin{tabular}{|c|c|c|c|c|c|c|c|c|c|c|c|}
\hline Parameter & & W-24 & $\mathrm{W}-25$ & W-26 & W-27 & W-28 & W-29 & W-30 & W-31 & $\begin{array}{c}\text { MVST } \\
\text { total }\end{array}$ & CITs \\
\hline \multirow{2}{*}{$\begin{array}{l}\text { Sludge vol, } \\
\text { gal }\end{array}$} & Initial & 13,200 & 23,400 & 15,100 & 17,700 & 3,800 & 11,000 & 11,000 & 6,400 & 101,600 & 0 \\
\hline & Final & 25,500 & 27,100 & 26,200 & 26,800 & 25,400 & 15,100 & 15,400 & 27,300 & 188,800 & 107 \\
\hline \multirow{2}{*}{$\begin{array}{l}\text { Supernate } \\
\text { vol, gal }\end{array}$} & Initial & 10,700 & 23,400 & 24,300 & 25,300 & 36,900 & 11,200 & 29,600 & 35,000 & 196,400 & 0 \\
\hline & Final & 2,000 & 1,960 & 1,930 & 1,960 & 2,020 & 7,500 & 12,400 & 2,030 & 32,300 & 295,000 \\
\hline \multirow{2}{*}{$\begin{array}{l}\text { Supernate } \\
\mathrm{NO}_{3} \text { conc., } \\
\mathrm{mol} / \mathrm{L}\end{array}$} & Initial & 3.18 & 3.85 & 4.82 & 5.52 & 6.85 & 3.33 & 4.88 & 5.02 & -- & -- \\
\hline & Final & 0.001 & 0.6 & 0.004 & 0.004 & 0.05 & 4.5 & 4.07 & 0.09 & -- & 5.06 \\
\hline \multirow{2}{*}{$\begin{array}{l}\text { Supernate } \\
{ }^{137} \mathrm{Cs} \text { conc., } \\
\mathrm{Bq} / \mathrm{mL}\end{array}$} & Initial & $1.1 \mathrm{E}+6$ & $1.2 \mathrm{E}+6$ & $1.4 \mathrm{E}+6$ & 3. $3 E+5$ & $6.2 \mathrm{E}+5$ & $5.0 \mathrm{E}+5$ & $5.6 \mathrm{E}+5$ & $4.8 \mathrm{E}+5$ & -- & -- \\
\hline & Final & $1.9 \mathrm{E}+3$ & $1.3 \mathrm{E}+5$ & $7.2 \mathrm{E}+3$ & $1.5 \mathrm{E}+3$ & $2.4 \mathrm{E}+4$ & $6.1 \mathrm{E}+5$ & $26 E+5$ & $4.2 E+4$ & -- & $6.02 \mathrm{E}+5$ \\
\hline
\end{tabular}


APPENDIX A:

WATER BALANCE SPREAD SHEET FOR BASELINE SCENARIO 
GAAT SLUDGE CONSOLIDATION IN W9 (except W8). SETTLING ONLY.

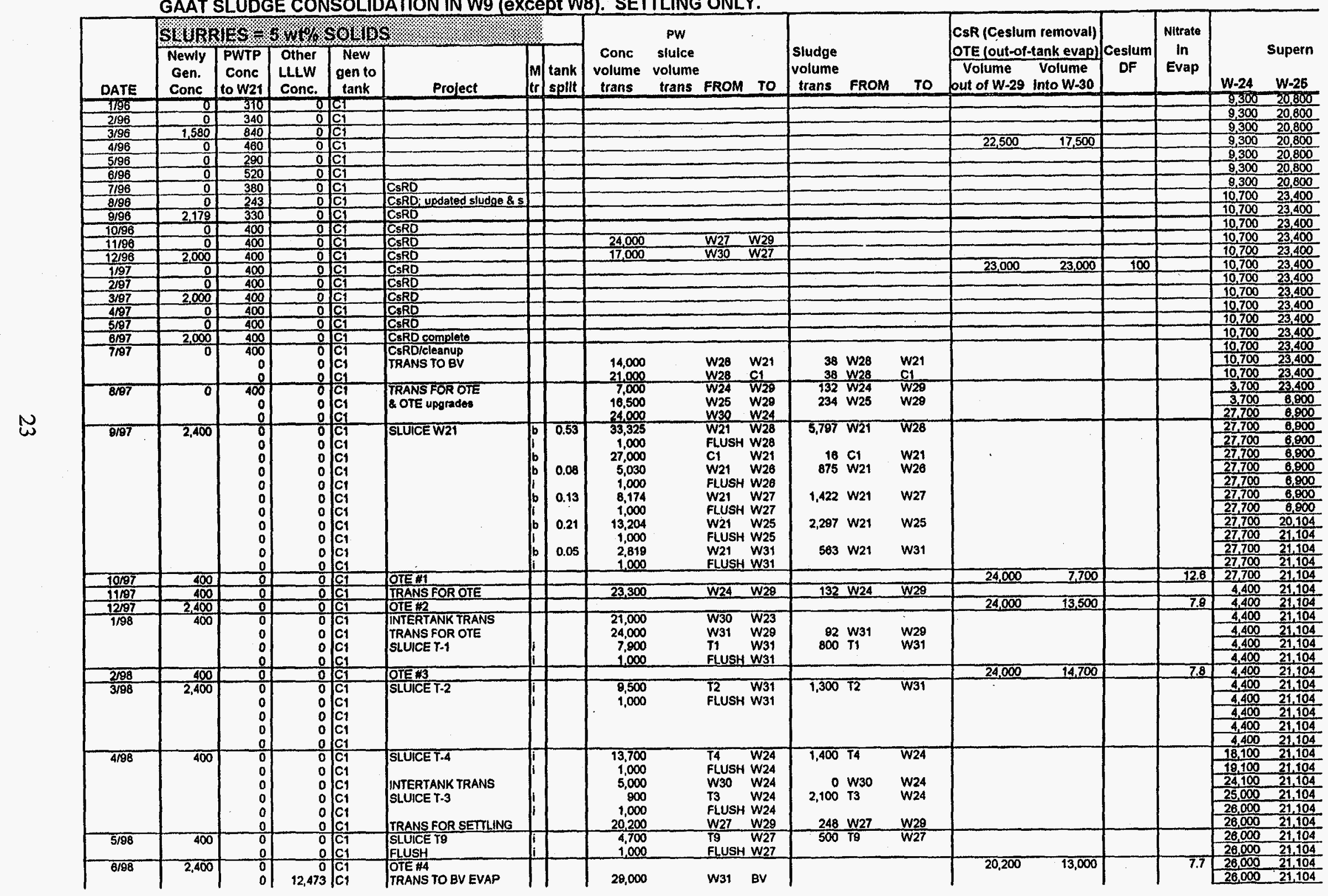


GAAT SLUDGE CONSOLIDATION IN W9 (except WB). SETTLING ONLY.

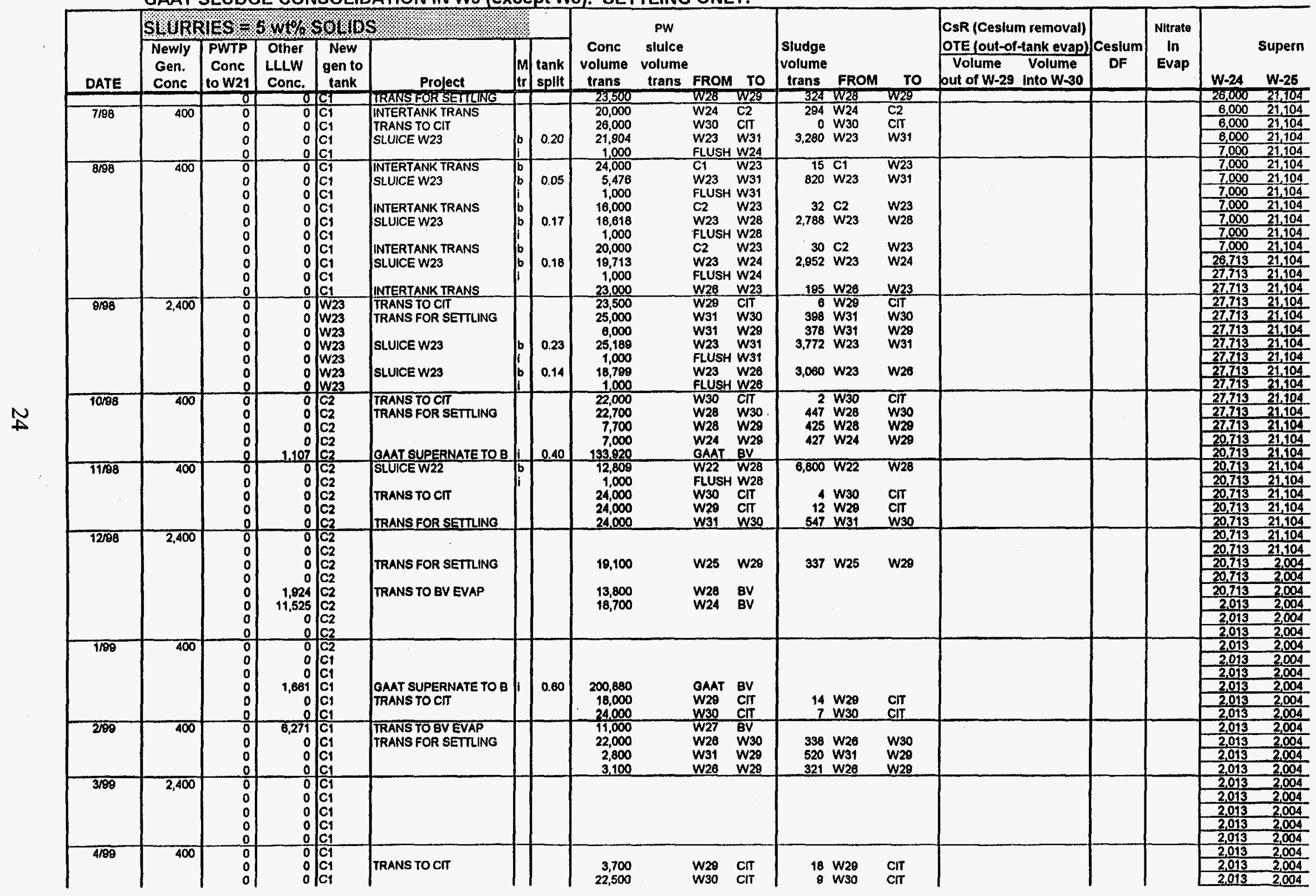




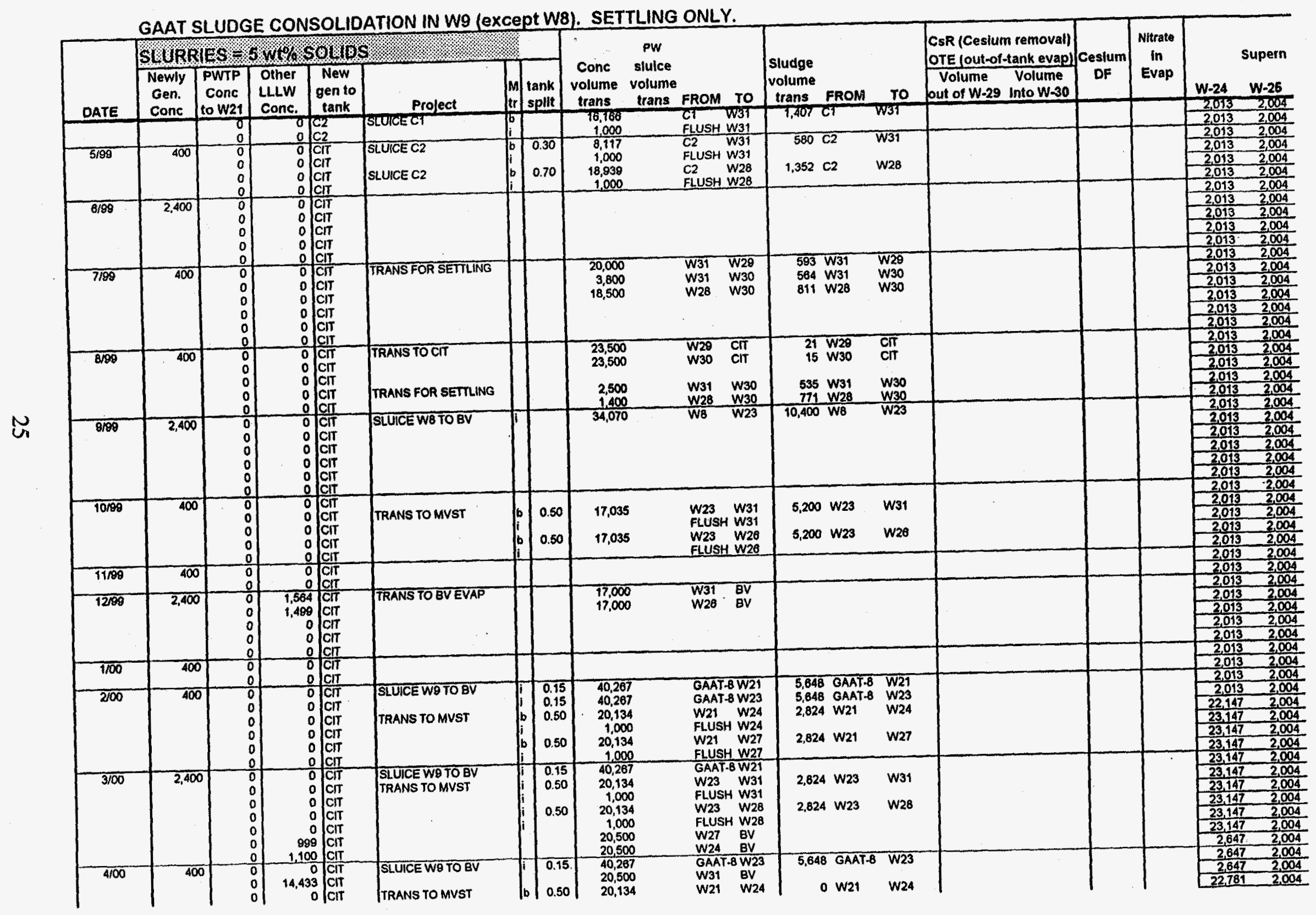


GAAT SLUDGE CONSOLIDATION IN W9 (except W8). SETTLING ONLY.

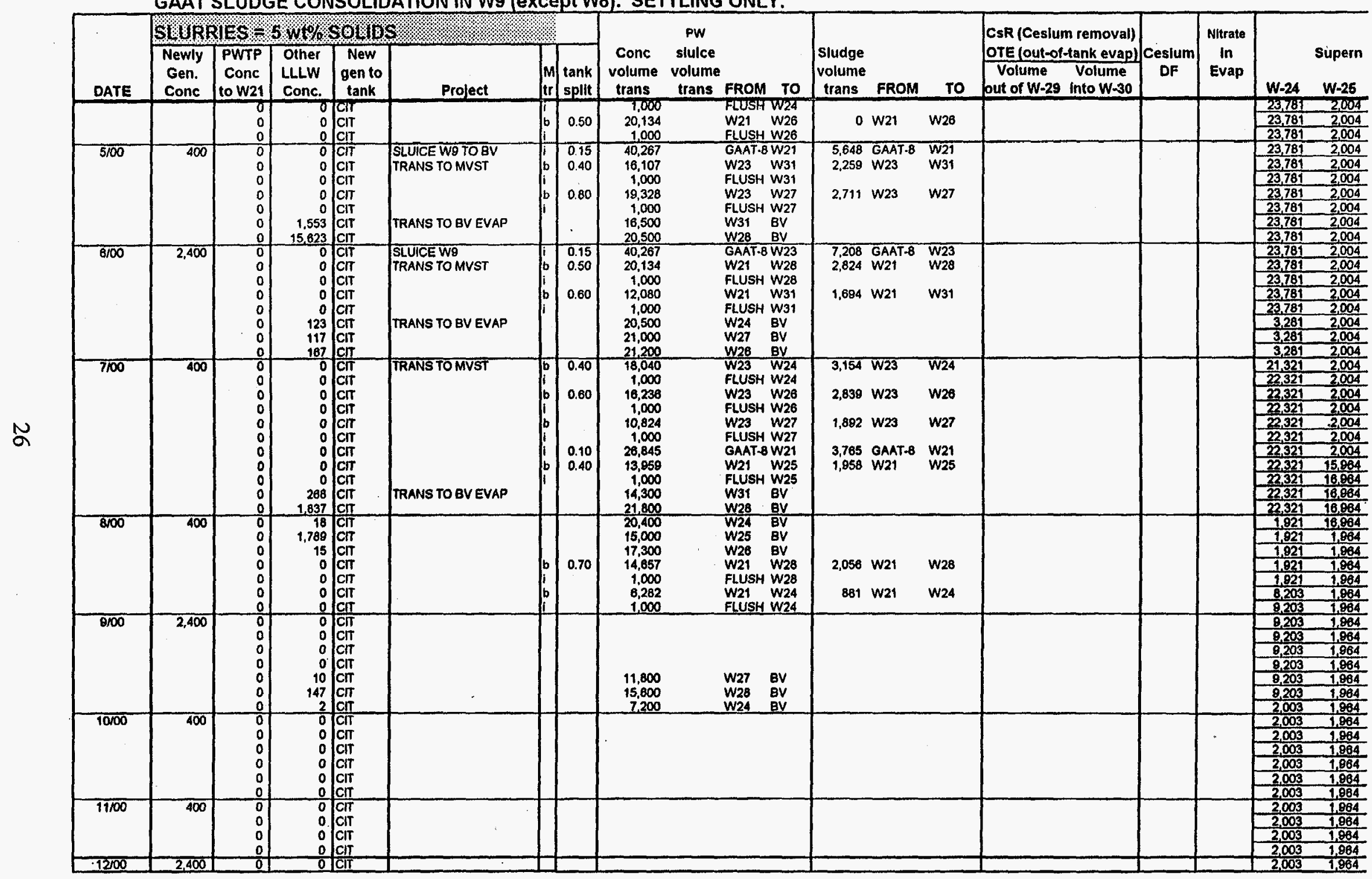




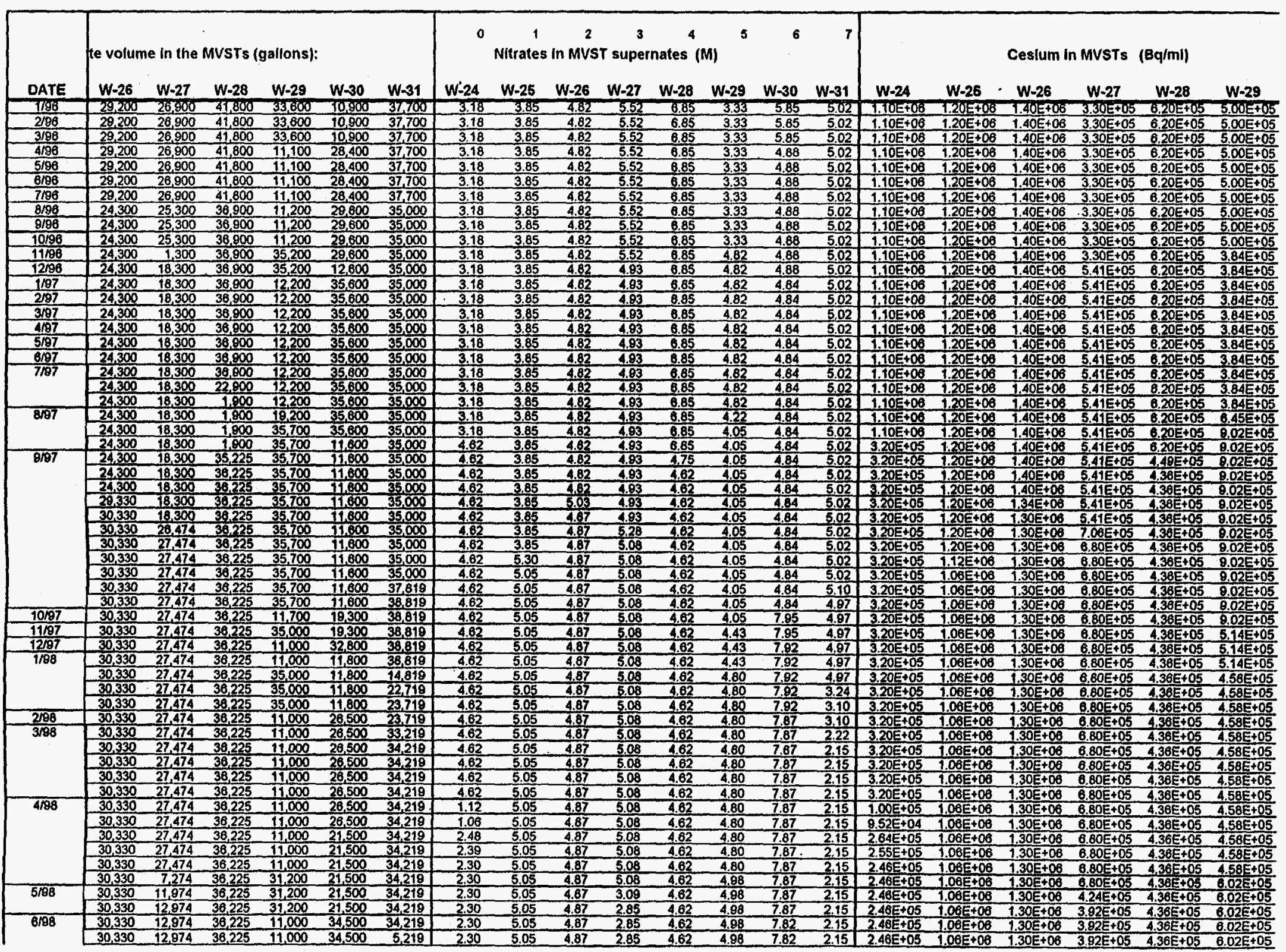




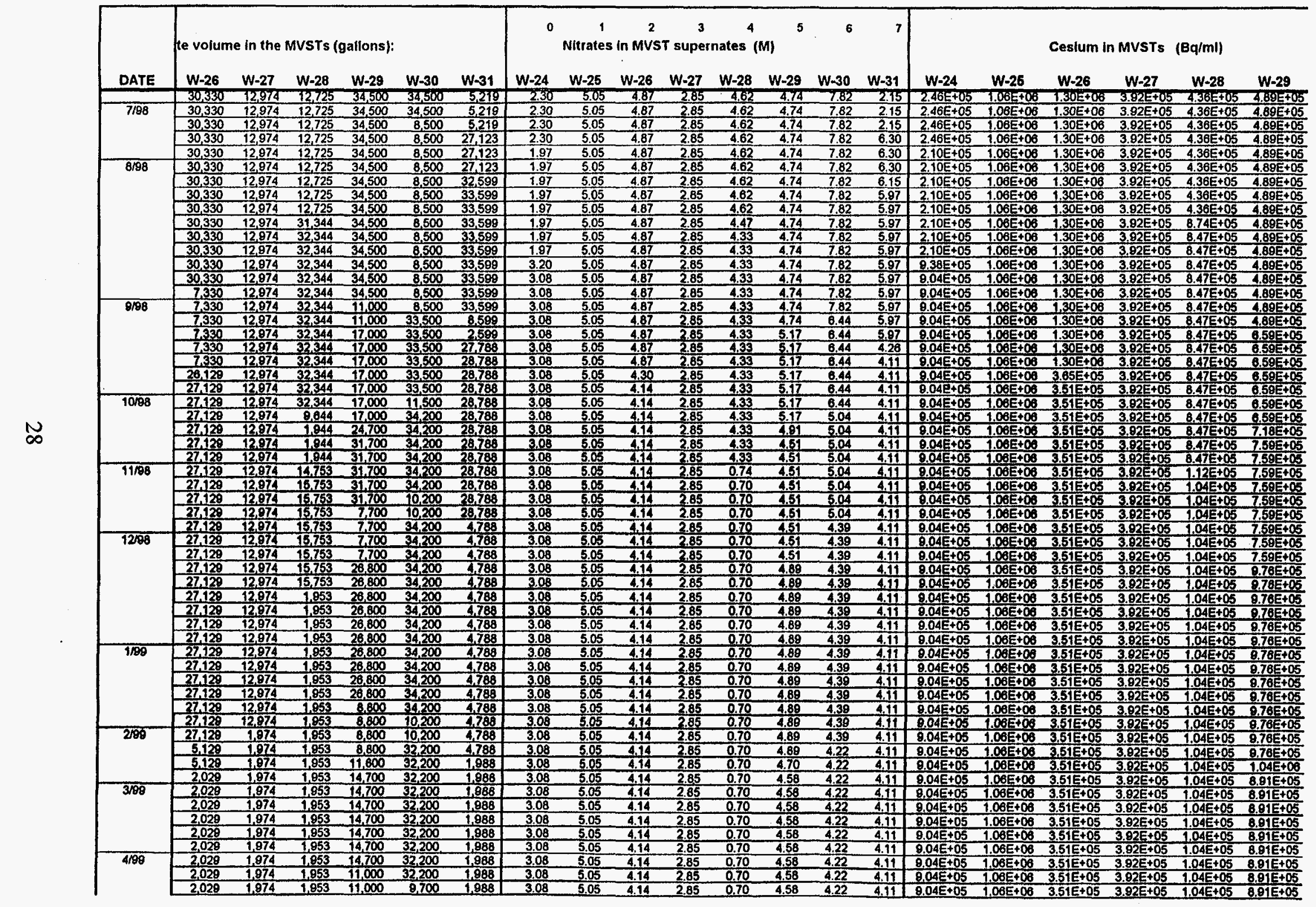




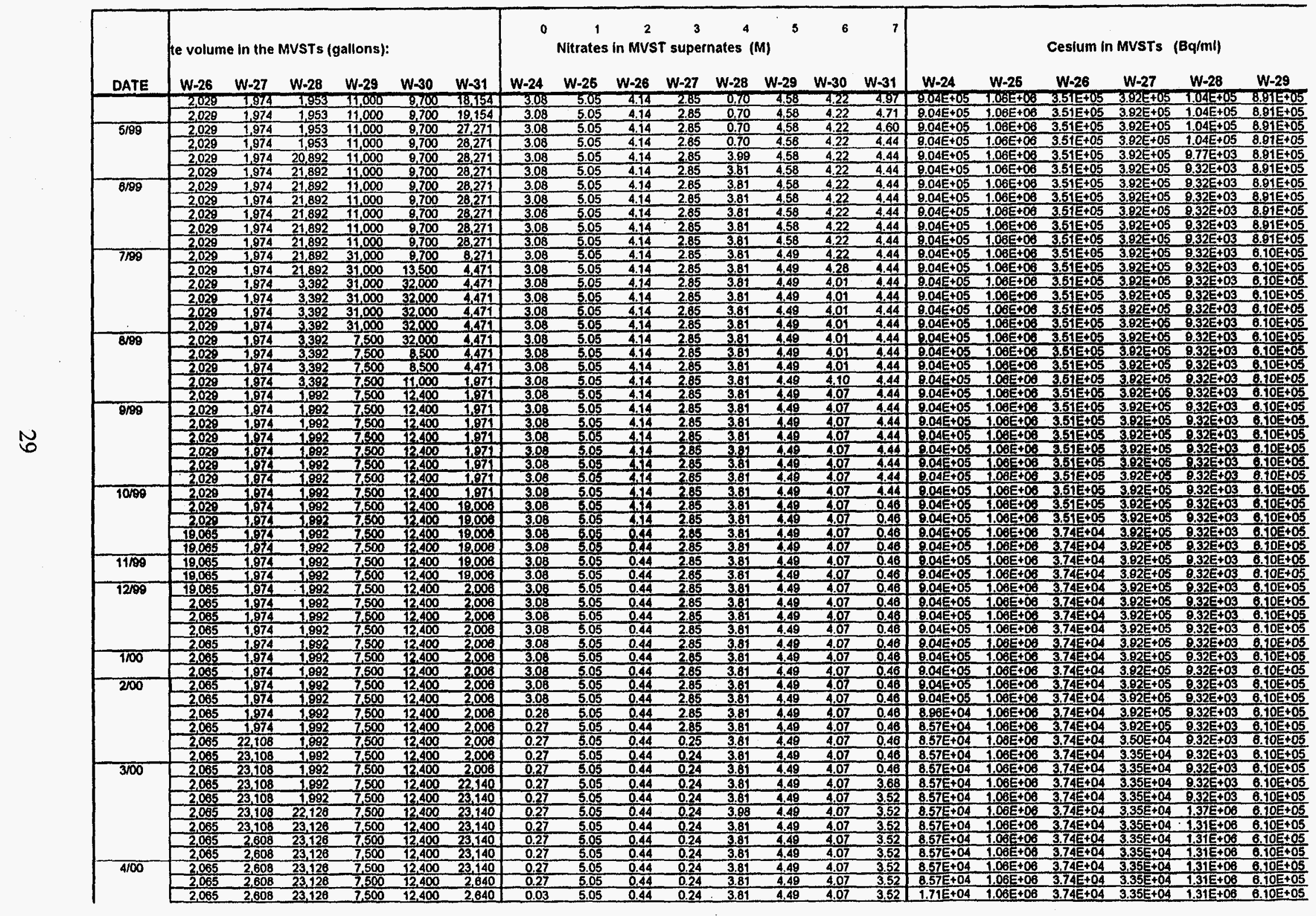




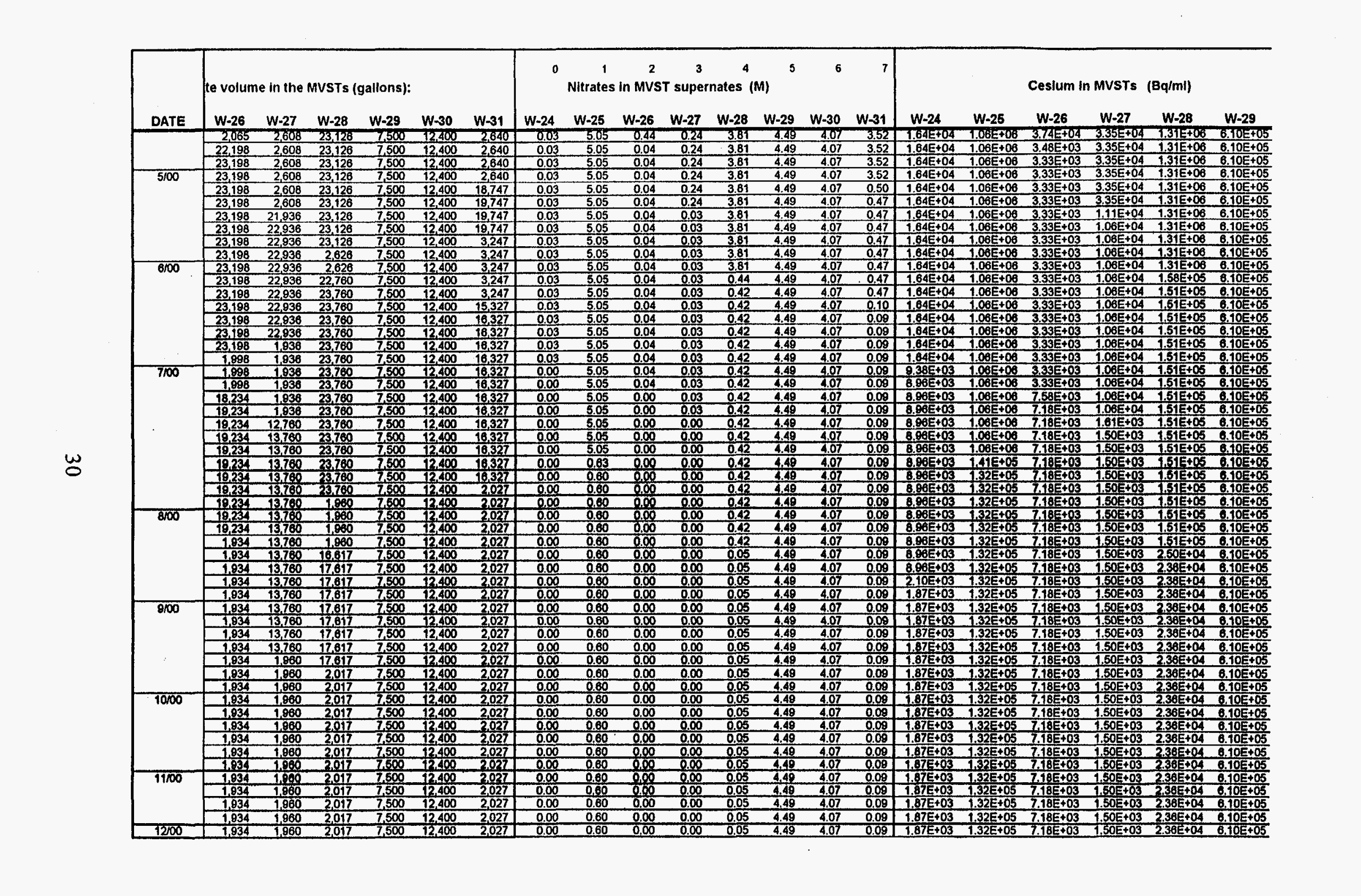




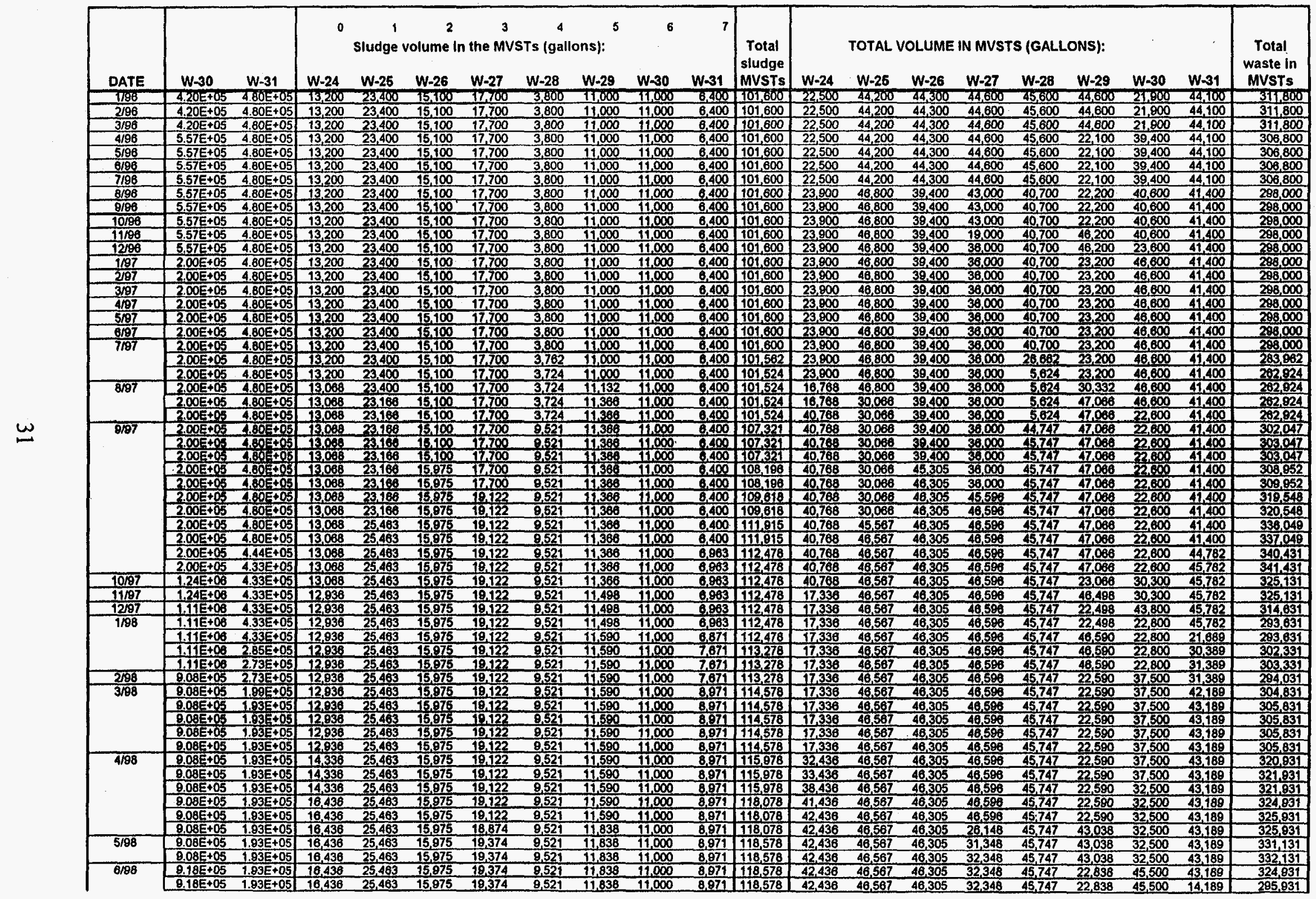




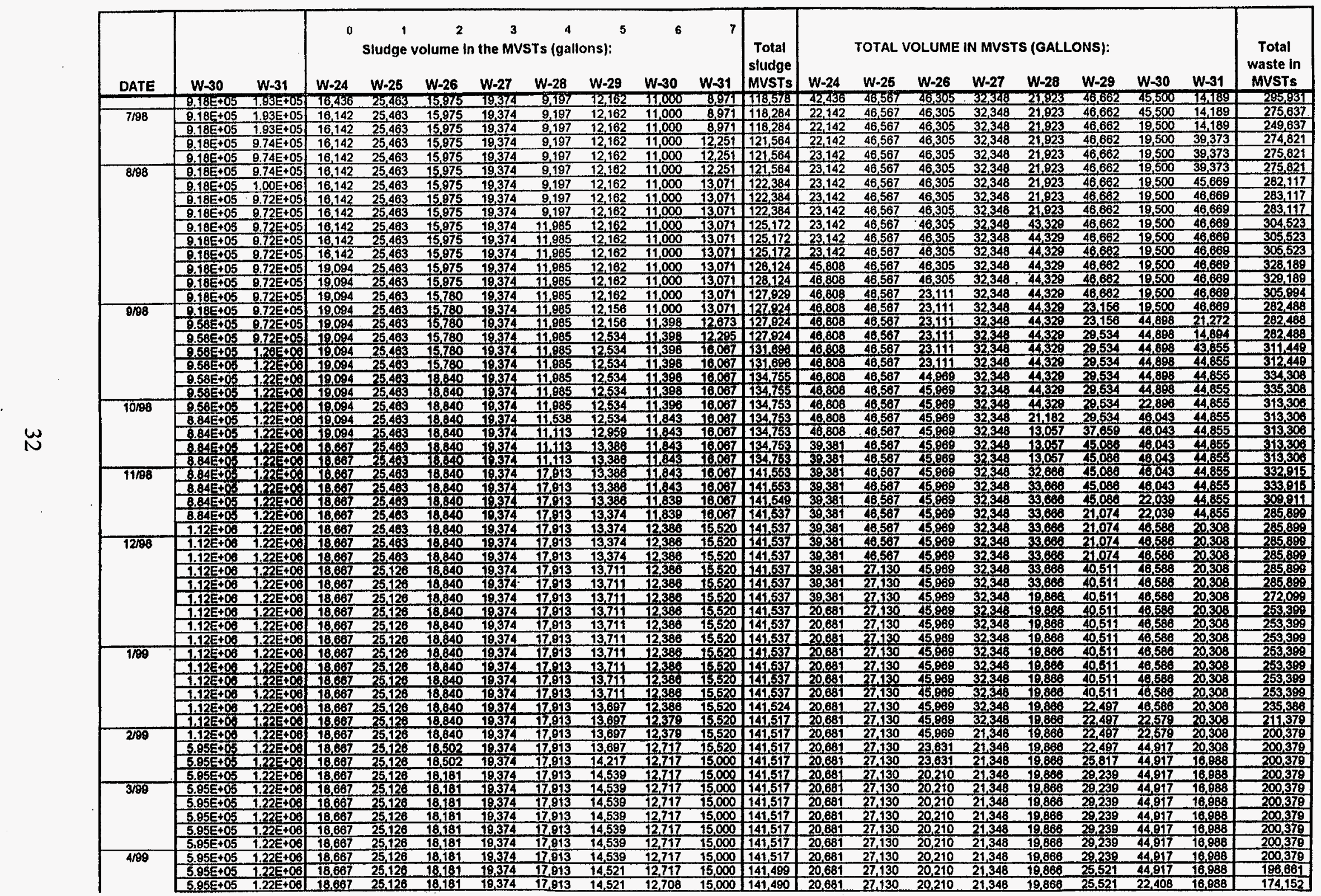




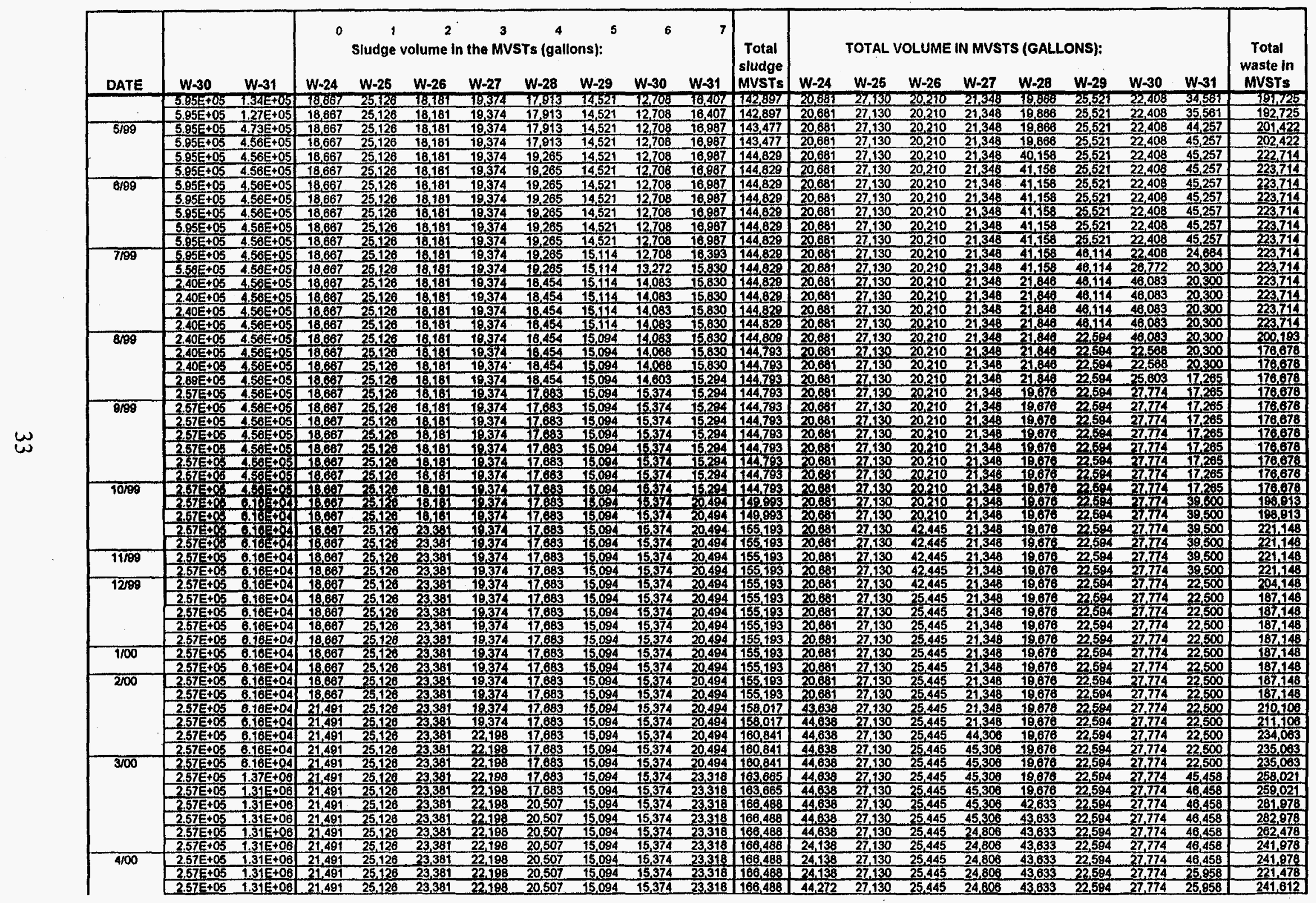




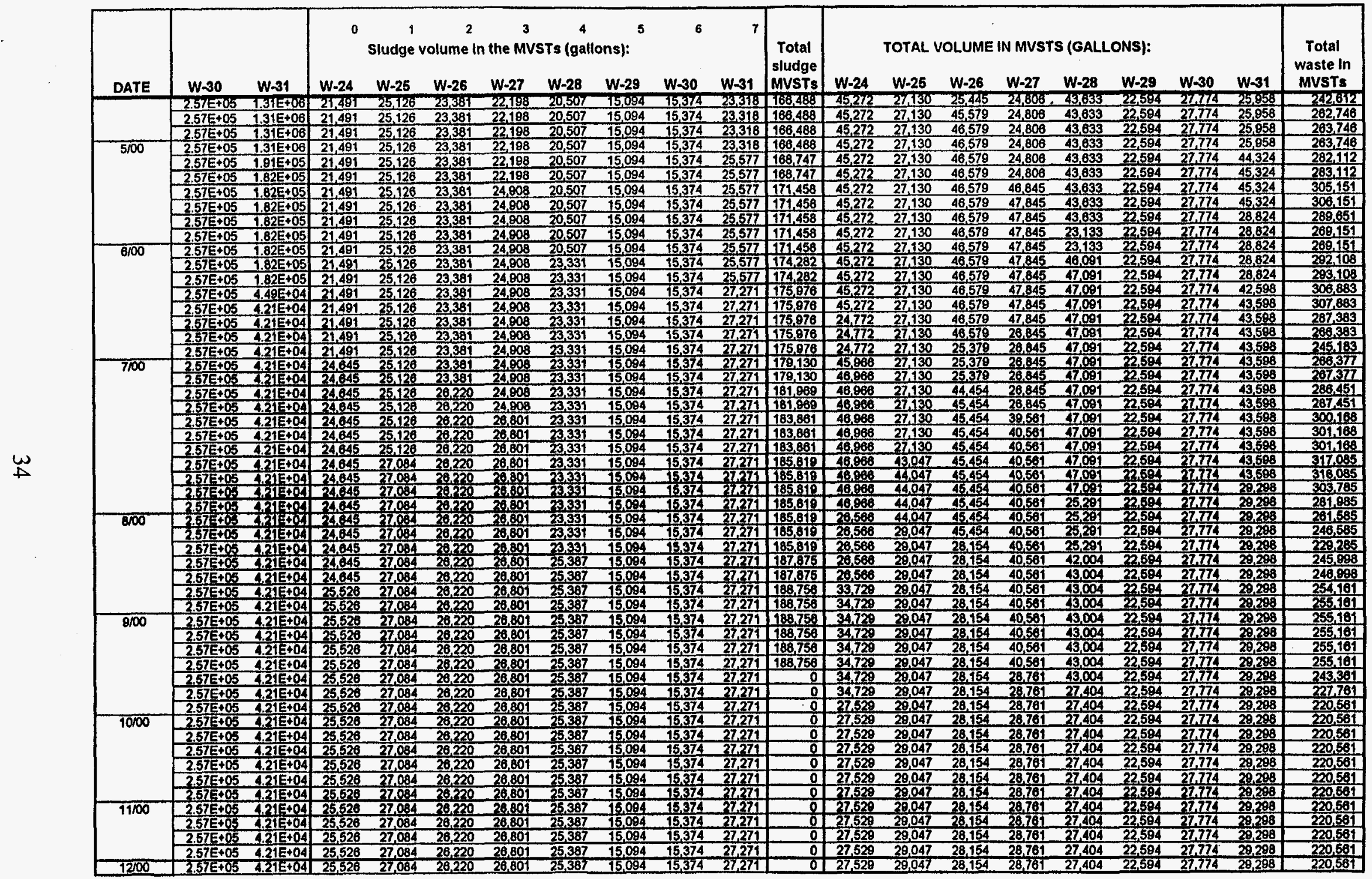




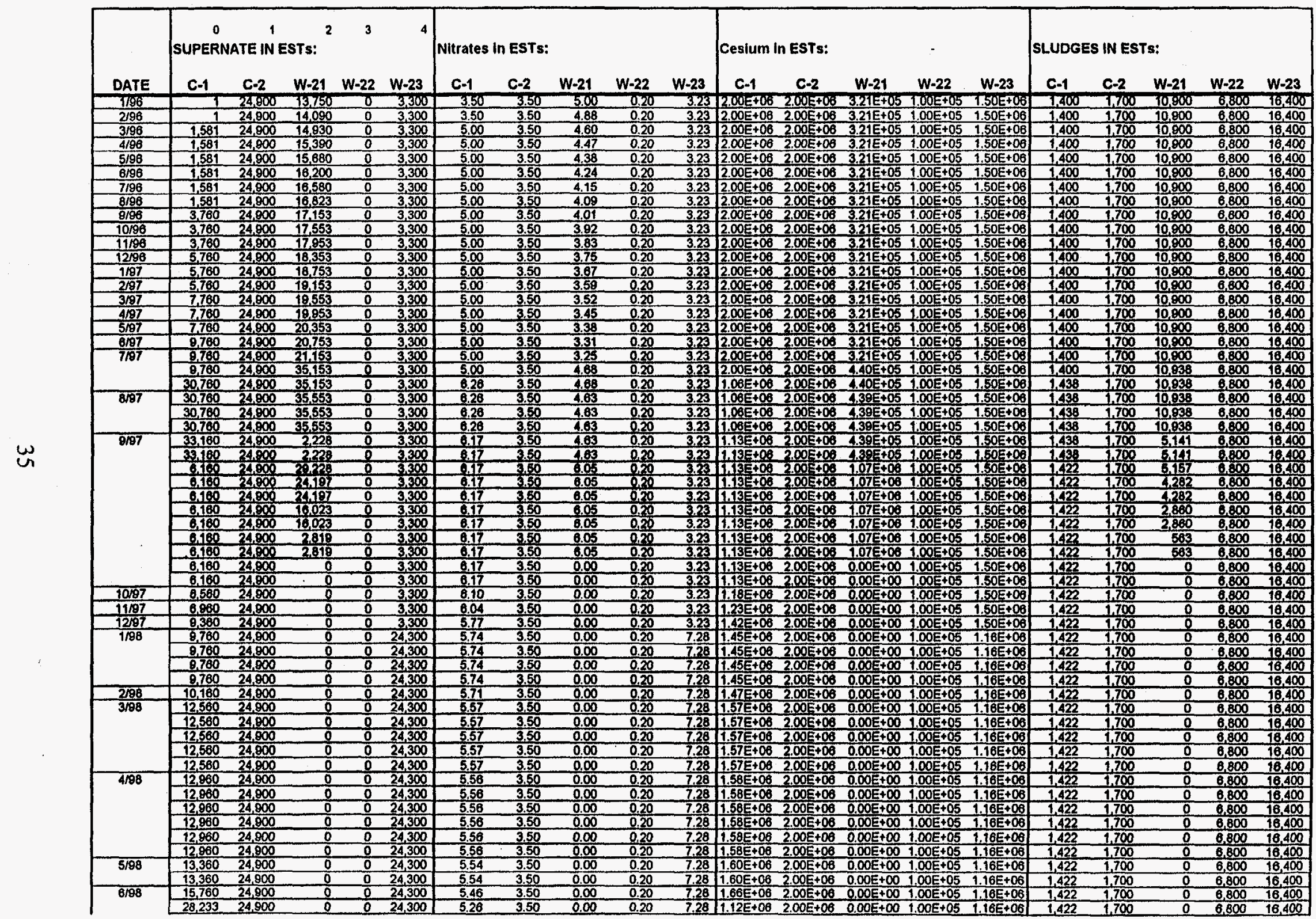




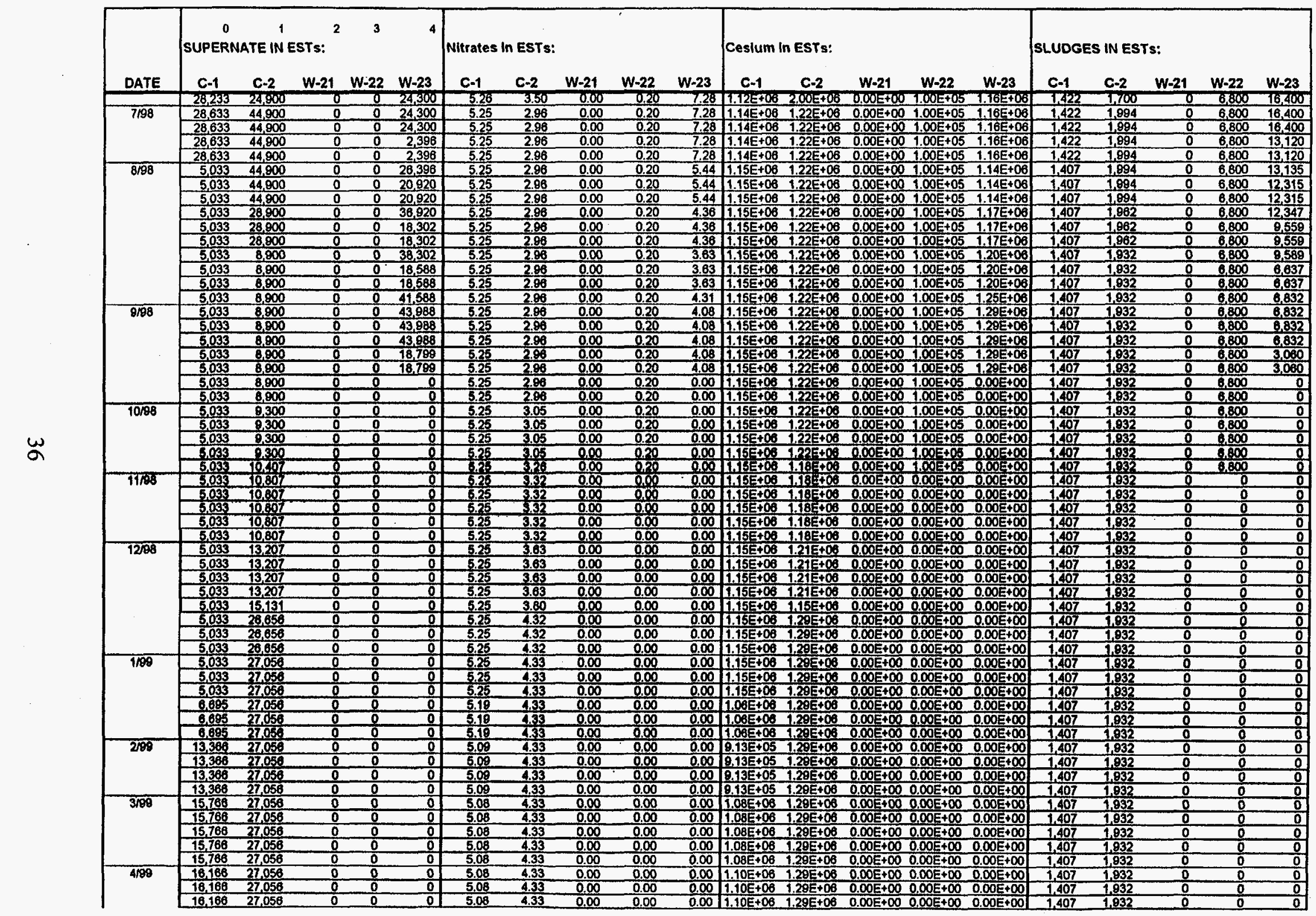





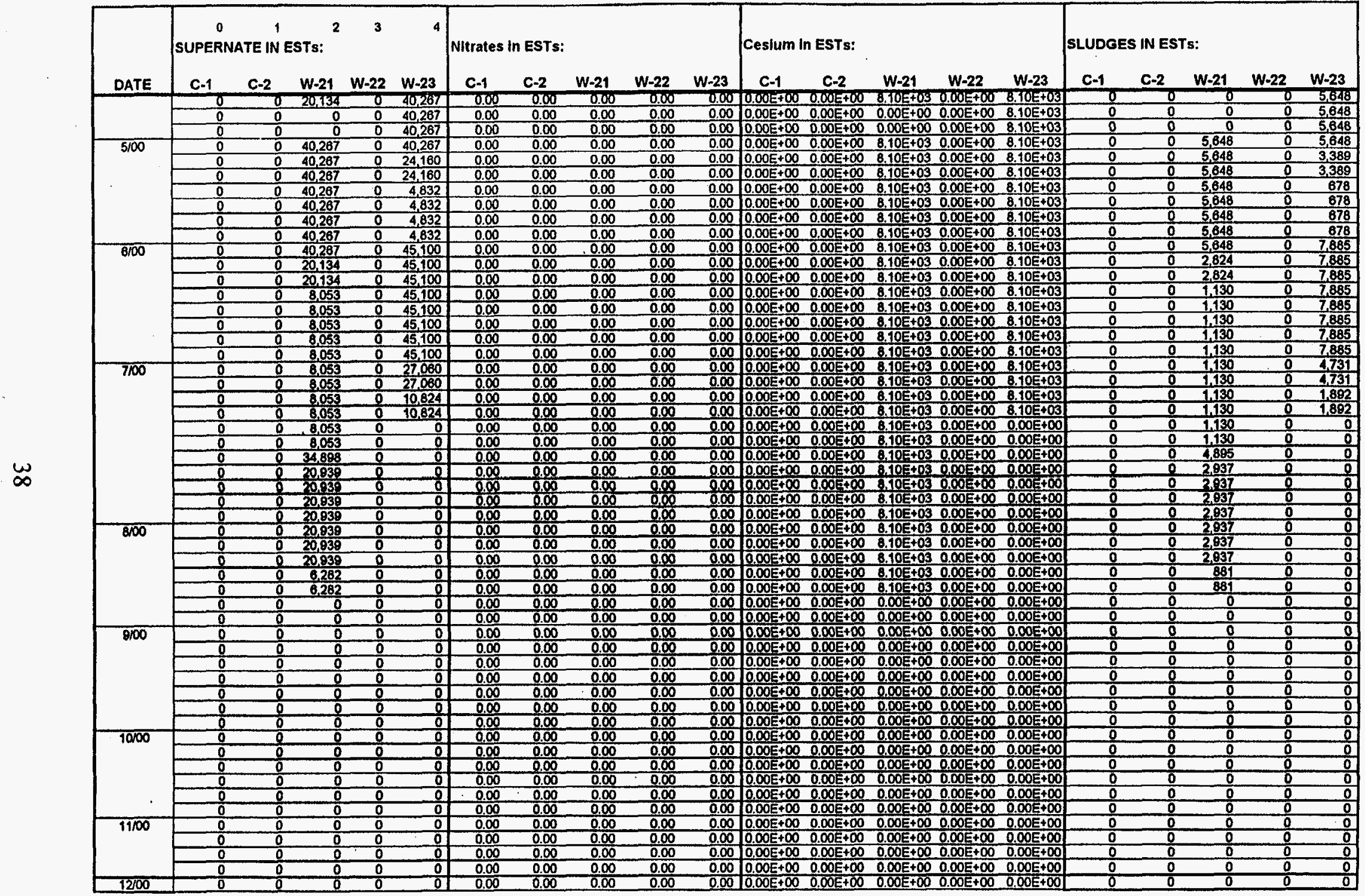




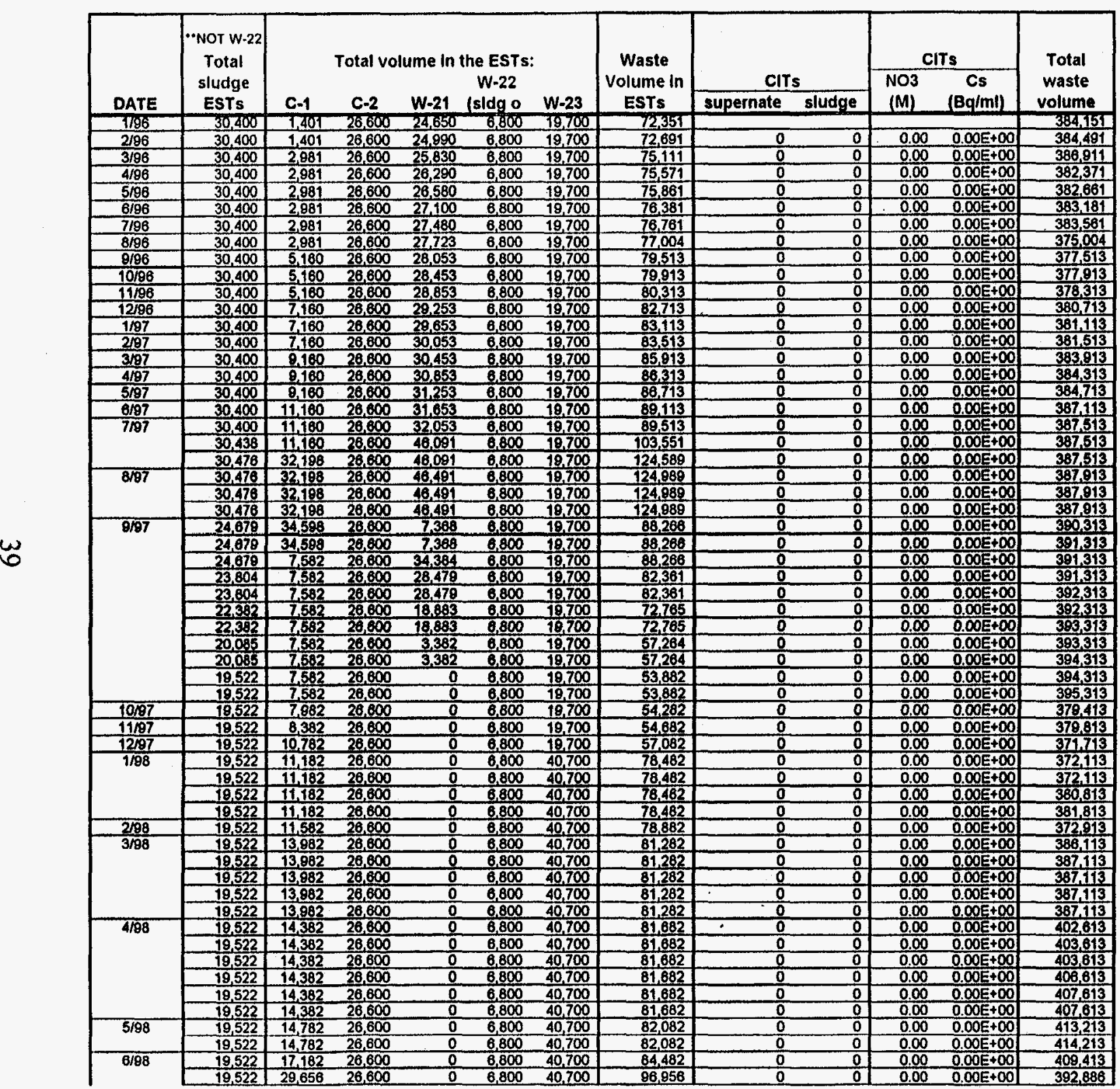




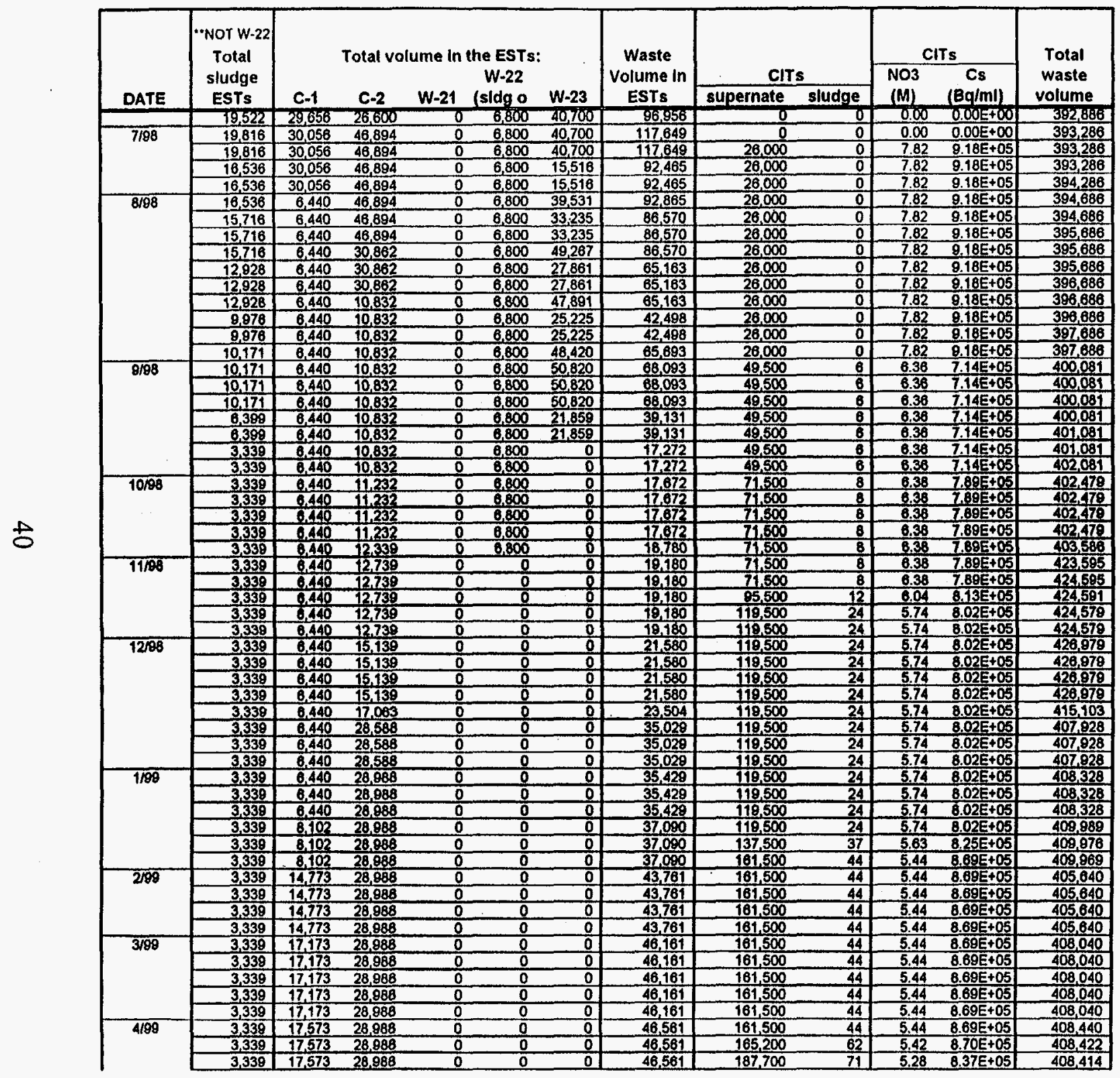




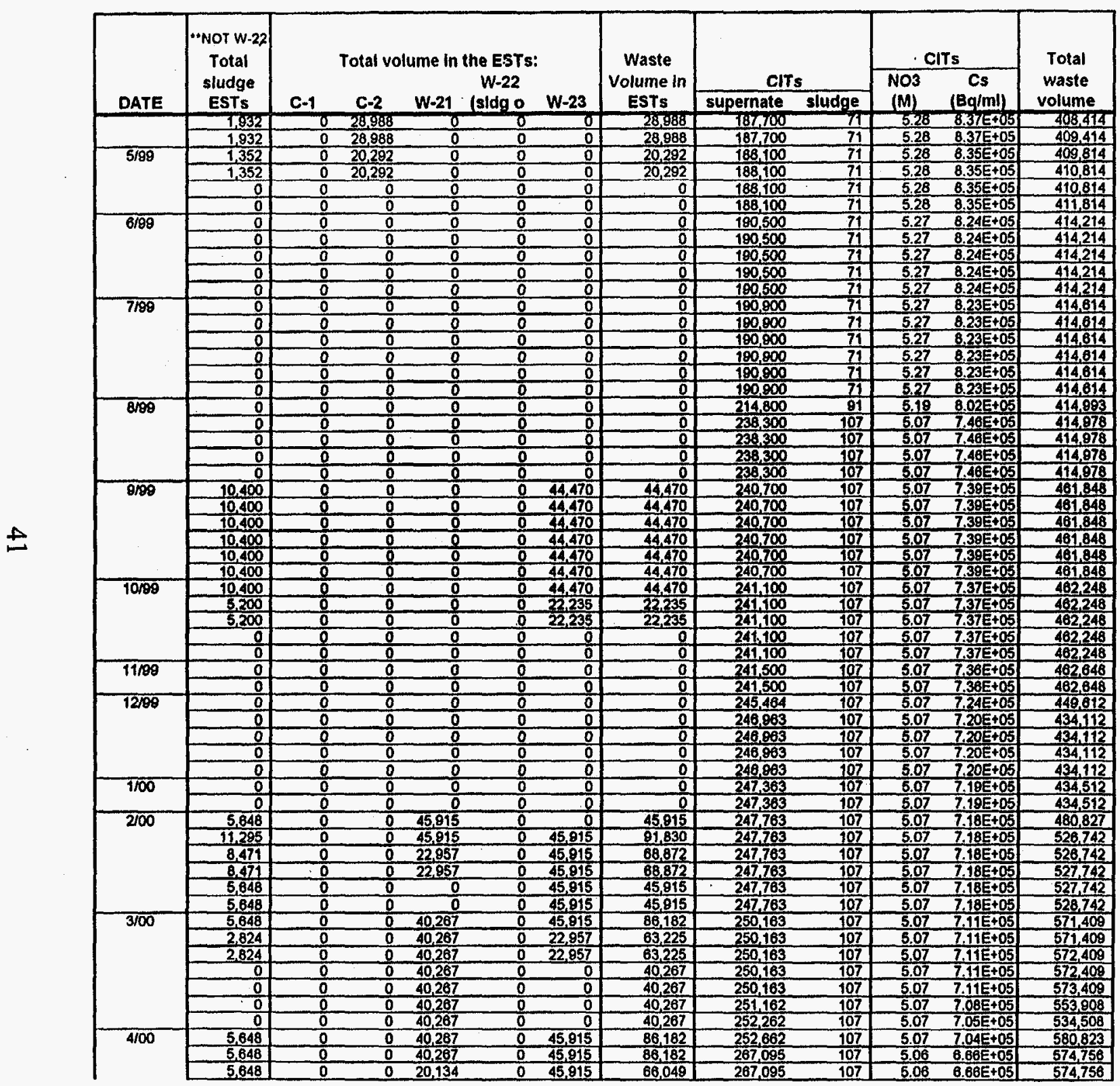




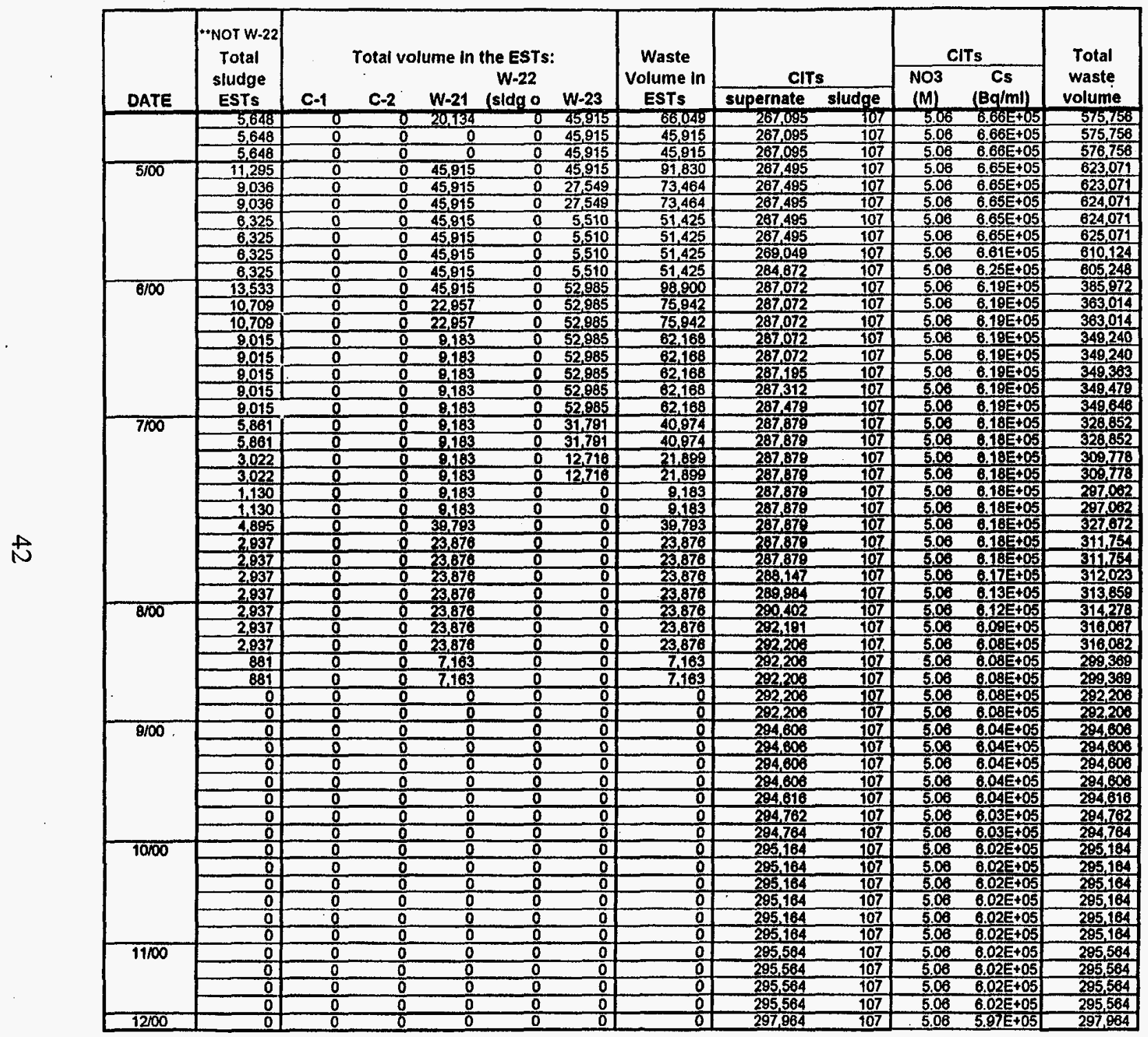




\section{Internal Distribution}

$\begin{aligned} 1-3 . & \text { J. S. Baldwin } \\ 4 . & \text { C. A. Bednarz } \\ 5 . & \text { J. M. Begovich } \\ 6 . & \text { C. H. Byers } \\ 7 . & \text { E. D. Collins } \\ 8 . & \text { T. B. Conley } \\ 9 . & \text { A. G. Croff } \\ 10-12 . & \text { S. M. DePaoli } \\ 13 . & \text { O. W. Hale } \\ 14 . & \text { T. D. Hylton } \\ 15 . & \text { M. A. Johnson } \\ 16 . & \text { R. T. Jubin } \\ 17-19 . & \text { T. E. Kent } \\ 20 . & \text { C. M. Kendrick } \\ 21 . & \text { B. E. Lewis } \\ 22 . & \text { J. M. Lynch } \\ 23 . & \text { J. J. Maddox } \\ 24 . & \text { R. C. Mason } \\ 25 . & \text { C. P. McGinnis } \\ 26 . & \text { L. E. McNeese }\end{aligned}$

27-29. T. H. Monk

30-32. J. W. Moore

33. T. E. Myrick

34. R. D. Nipper, Jr.

35. B. D. Patton

36. J. H. Platfoot

37. D. E. Reichle

38-40. S. M. Robinson

41. S. T. Rudell

42. T. F. Scanlan

43. C. B. Scott

44. J. L. Stellern

45. J. R. Trabalka

46. S. D. Van Hoesen

47. A. B. Walker

48. J. R. Walker, Jr.

49. T. D. Welch

50. J. H. Wilson

51. Laboratory Records-RC

52. WMRAD Document Management Center

\section{External Distribution}

53. S. Gibson, USDOE, 3 Main, Oak Ridge, TN 37830

54. C. S. Mims, USDOE, 3 Main, Oak Ridge, TN 37830

55. J. Noble-Dial, USDOE, 3 Main, Oak Ridge, TN 37830

56. G. Riner, USDOE, 3 Main, Oak Ridge, TN 37830

57-58. Office of Scientific and Technical Information, P.O. Box 62, Oak Ridge, TN 37830 